\title{
Synthesis and Characterization of Di- and Tetracarbene Iron(II) Complexes with Chelating N-Heterocyclic Carbene Ligands and Their Application in Aryl Grignard-Alkyl Halide Cross-Coupling
}

\author{
Steffen Meyer, Claudia Manuela Orben, Serhiy Demeshko, Sebastian Dechert, and Franc Meyer* \\ Institut für Anorganische Chemie, Georg-August-Universität Göttingen, Tammannstrasse 4, D-37077 Göttingen, Germany
}

Supporting Information

ABSTRACT: A series of new and known bis(imidazolium) chloride and bromide salts bridged by either a methylene group $(\mathbf{1 - 8}, \mathbf{1 0 a}, \mathbf{b})$ or an ethylene group $(\mathbf{9 a}, \mathbf{b})$ and bearing different $\mathrm{N}$ substituents ( $\mathrm{Me}, \mathrm{Et}, \mathrm{Bn}, t \mathrm{Bu}, \mathrm{Mes}$ ) have been reacted with $\left[\mathrm{Fe}\left\{\mathrm{N}\left(\mathrm{SiMe}_{3}\right)_{2}\right\}_{2}\right]_{2}$ to yield the four-coordinate iron(II) complexes $\left[\mathrm{LFeX}_{2}\right](\mathbf{1 1 - 2 0} ; \mathrm{X}=\mathrm{Cl}, \mathrm{Br} ; \mathrm{L}=$ chelating bis(imidazolylidene) ligand). Molecular structures of six of these complexes have been characterized by X-ray crystallography, and selected examples have been characterized by ${ }^{1} \mathrm{H}$

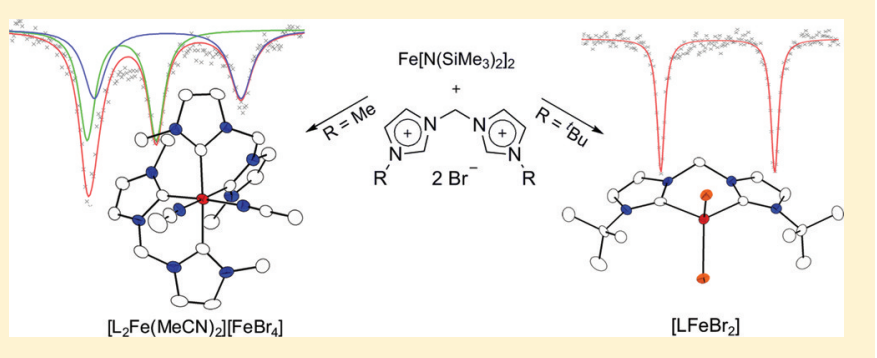
NMR and UV-vis spectroscopy, cyclic voltammetry, Mössbauer spectroscopy, and SQUID magnetometry. In all cases the iron(II) is found in a distorted-tetrahedral environment; it is in the high-spin state and shows large quadrupole splittings in the range $3.67-4.03 \mathrm{~mm} \cdot \mathrm{s}^{-1}\left(\delta=0.73-0.81 \mathrm{~mm} \cdot \mathrm{s}^{-1}\right)$. Subtleties of the metric parameters depend on the bridging unit between the two imidazolylidene groups, the peripheral $\mathrm{N}$ substituents, and the coligand $(\mathrm{Cl}$ or $\mathrm{Br})$. In case of rather small $(\mathrm{Me}, \mathrm{Et})$ or flexible $(\mathrm{Bn}) \mathrm{N}$ substituents the dicarbene species $\left[\mathrm{LFeX}_{2}\right]$ are formed together with ferrous tetracarbene complexes $\left[\mathrm{L}_{2} \mathrm{FeX}_{2}\right](\mathbf{2 1 - 2 3})$, which are difficult to separate and could not be isolated in pure form. When the latter are dissolved in $\mathrm{MeCN}$ in the presence of residual $\left[\mathrm{FeBr}_{2}(\mathrm{solv})_{x}\right]$, however, they transform into the ionic complexes $\left[\mathrm{L}_{2} \mathrm{Fe}(\mathrm{MeCN})_{2}\right]\left[\mathrm{FeBr}_{4}\right]($ 24-26), which have been characterized by single-crystal X-ray diffraction. They feature lowspin iron(II) (Mössbauer parameters $\delta \approx 0.15 \mathrm{~mm} \mathrm{~s}^{-1}, \Delta E_{\mathrm{Q}} \approx 1.36 \mathrm{~mm} \mathrm{~s}^{-1}$ ) and distorted-octahedral structures with the two $\mathrm{MeCN}$ ligands in a cis configuration. Selected examples of the new dicarbene complexes $\left[\mathrm{LFeX}_{2}\right]$ have been tested as catalysts for the standard cross-coupling reaction between $p$-tolylmagnesium bromide and bromo- or chlorocyclohexane. They show moderate activity that appears to be generally lower than for related complexes with two monodentate NHC ligands, but the activities clearly depend on the peripheral $\mathrm{N}$ substituents and the linker between the two imidazolylidene groups; the best results are obtained for complex 19, which features a long ethylene bridge and bulky Mes substituents, and hence the most shielded metal center.

\section{INTRODUCTION}

$\mathrm{N}$-heterocyclic carbenes (NHCs) have gained great popularity as ligands in organometallic chemistry and are finding widespread use in homogeneous catalysis. ${ }^{1,2}$ They are usually viewed as strongly $\sigma$-donating ligands with little or negligible $\pi$ back-bonding. Chemical and substitutional inertness is often mentioned among their particular advantages, and this is expected to be further amplified by incorporating the NHC moiety into a chelating scaffold. Mainly in the past decade a variety of iron complexes with monodentate NHC ligands ${ }^{3-5}$ and several NHC ligated iron clusters have been published. ${ }^{6}$ Some of the mononuclear iron NHC complexes ${ }^{4,5}$ as well as species generated in situ from imidazolium salts and suitable iron precursors showed high activities in homogeneous catalysis. ${ }^{7,8}$ However, only a few iron complexes with chelating bis- or tris(imidazolylidene) ligands are known so far. These comprise iron complexes with tridentate 2,6-bis(imidazolylidene)pyridine, ${ }^{9}$ tris(imidazolylidene)borate, ${ }^{10}$ and tris(imidazolylidene)triethylamine ${ }^{11}$ as well as methylenebridged bis(imidazolylidene) $)^{3 \mathrm{~d}, 12}$ ligands. The latter have also been employed in model systems for $[\mathrm{FeFe}]$-hydrogenases. ${ }^{13}$
More generally, bidentate methylene- or ethylene-bridged bis(imidazolylidene) ligands are quite popular scaffolds for transition-metal catalysts, especially in palladium chemistry. ${ }^{14}$ Among the reasons are the simple preparation of the respective bis(imidazolium) salts, the precursors of NHC ligands, and the relatively high stability of the bis(imidazolylidene) species. The synthesis of NHC complexes is usually performed in situ by deprotonation of the imidazolium salts and subsequent treatment with metal complexes (Scheme 1 ; route $\mathrm{A}$ ), by direct reaction of the imidazolium salt with metal compounds containing basic ligands (route B), or by cyclization of metal-bound isocyanides (route C). ${ }^{31,15}$

Almost all iron NHC complexes reported so far have been prepared via route $A,{ }^{3,6}$ while palladium $\mathrm{NHC}$ complexes are often prepared according to route $\mathrm{B}$ by the use of $\mathrm{Pd}(\mathrm{OAc})_{2}{ }^{16}$ In contrast, $\mathrm{Fe}(\mathrm{OAc})_{2}$ has not yet been successfully used for NHC complex synthesis, and our attempts have also failed.

Received: September 15, 2011

Published: November 17, 2011 
Scheme 1. Typical Routes for the Synthesis of TransitionMetal NHC Complexes

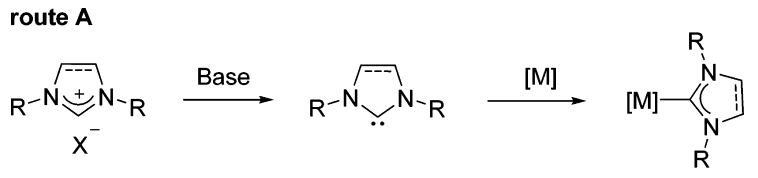

route $B$
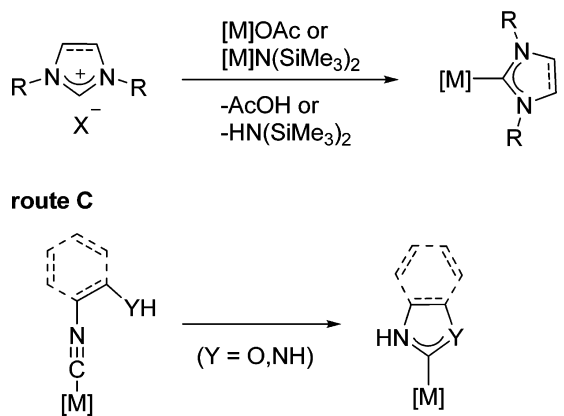

Some iron NHC complex syntheses have been reported using $\left[\mathrm{Fe}\left\{\mathrm{N}\left(\mathrm{SiMe}_{3}\right)_{2}\right\}_{2}\right]_{2}$ or $\left[\mathrm{Cp} * \mathrm{FeN}\left(\mathrm{SiMe}_{3}\right)_{2}\right]$ for imidazolylidene formation and complexation. ${ }^{3 \mathrm{~g}, 9 \mathrm{~b}, \mathrm{e}}$ Since the only side product, hexamethyldisilazane, is rather unreactive and can be removed by evaporation, and since $\left[\mathrm{Fe}\left\{\mathrm{N}\left(\mathrm{SiMe}_{3}\right)_{2}\right\}_{2}\right]_{2}$ is readily accessible, ${ }^{17}$ we have chosen route $\mathrm{B}$ for the present study. The bis-chelate NHC iron(II) dihalide complexes presented herein are related to monodentate NHC iron(II) dihalide complexes initially reported by Grubbs et al. ${ }^{3 \mathrm{~b}}$ and recently investigated by Deng et al. ${ }^{3 \mathrm{n}}$ (Scheme 2), which in both cases were synthesized via route $A$.

Scheme 2. Dicarbene Iron(II) Dihalide Complexes Synthesized by Grubbs et al. $\left(\mathrm{X}=\mathrm{Br}, \mathrm{Cl} ; \mathrm{R}={ }^{i} \mathrm{Pr}\right)^{3 \mathrm{~b}}$ and Deng et al. $(\mathrm{X}=\mathrm{Cl}$; $\left.\mathrm{R}=\mathrm{Me}, \mathrm{Et},{ }^{i} \mathrm{Pr}\right)^{3 \mathrm{n}}$

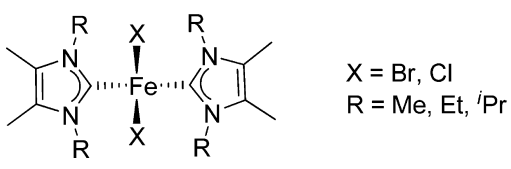

We report the synthesis and characterization of several new iron(II) bis-chelate NHC complexes that are accessible via in situ carbene generation using the respective bis(imidazolium) salts and $\left[\mathrm{Fe}\left\{\mathrm{N}\left(\mathrm{SiMe}_{3}\right)_{2}\right\}_{2}\right]_{2}$. Depending on the ligand substituents, either dicarbene iron complexes or mixtures of dicarbene and tetracarbene iron complexes are formed. For each type of complexes several representative examples have been analyzed by X-ray diffraction. The catalytic activity of selected dicarbene iron complexes is examined in a benchmark aryl Grignard-alkyl halide cross-coupling reaction. During the final stages of the preparation of this paper, similar dicarbene complexes were reported by Zlatogorsky et al. ${ }^{18}$

\section{RESULTS AND DISCUSSION}

Synthesis of Bis(imidazolium) Salts 1-10. The preparation of bis(imidazolium) salts was performed in an ACS glass autoclave by stirring the reactants for $1-3$ days at $110{ }^{\circ} \mathrm{C}$ (DCM) or $130{ }^{\circ} \mathrm{C}$ (THF) in analogy to the procedure reported by Scherg et al., ${ }^{19}$ although yields of the known salts $1-3,5,6$, $7 \mathbf{a}$ and $8 \mathbf{a}-10 \mathbf{a}^{19-24}$ were in most cases lower via this route (Table 1). Reaction conditions and workup of the chloride salts $\mathbf{6 b}-\mathbf{1 0 b}$ as well as the phenyl-substituted bromide salt 4 have been slightly modified compared to the literature procedure (see the Experimental Section). Prior to further use the bis(imidazolium) salts were evaporated to absolute dryness in high vacuum $\left(10^{-3} \mathrm{mbar}\right)$ at $100-150{ }^{\circ} \mathrm{C}$ (i.e., below the melting point). The absence of residual $\mathrm{H}_{2} \mathrm{O}$ was checked by ${ }^{1} \mathrm{H}$ NMR spectroscopy. This procedure is necessary, because most bis(imidazolium) salts are hygroscopic and $[\mathrm{Fe}\{\mathrm{N}$ $\left.\left.\left(\mathrm{SiMe}_{3}\right)_{2}\right\}_{2}\right]_{2}$, which is used in the following step, is highly water and oxygen sensitive. Bis(imidazolium) salts $4,6 \mathbf{b}, 7 \mathbf{b}$ and $10 \mathrm{~b}$ have not been reported before and have been fully characterized. 4 was analyzed by X-ray diffraction, since no molecular structure of any $\mathrm{CHPh}$-bridged bis(imidazolium) salt has been published yet. Colorless single crystals were obtained by slow diffusion of $\mathrm{Et}_{2} \mathrm{O}$ into a $\mathrm{MeCN}$ solution. The molecular structure of 4, which crystallizes in the monoclinic space group $P 2_{1} / n$, is shown in Figure S3 (Supporting Information). The angle formed by the two imidazolium rings is $72.9^{\circ}$; the rings are bridged by $\mathrm{C} 4$ with an $\mathrm{N} 1-\mathrm{C} 4-\mathrm{N} 3$ angle of $106.9^{\circ}$. The $\mathrm{C} 1 / 5-\mathrm{N}$ distances of the imidazolium rings lie within a range of $1.32-1.34 \AA$ with $\mathrm{N}-\mathrm{C}-\mathrm{N}$ angles of $107.7^{\circ}$ (N3-C5-N4) and $108.4^{\circ}(\mathrm{N} 1-\mathrm{C} 1-\mathrm{N} 2)$. The protons $\mathrm{H} 1, \mathrm{H} 4$, and $\mathrm{H} 5$ form rather short $\mathrm{C}-\mathrm{H} \cdots \mathrm{Br}$ hydrogen bonds $(2.57-2.82 \AA)$ to the counteranions; these distances are in the common range and are in accordance with values reported for compounds with

Table 1. Yields of Bis(imidazolium) Salts 1-10 (Left) and Iron(II) NHC Complexes 11-20 (Right)

\begin{tabular}{|c|c|c|c|c|c|c|c|c|c|}
\hline salt & $\mathrm{R}$ & $\mathrm{Y}$ & $\mathrm{X}$ & found (lit.) yield/\% & complex & $\mathrm{R}$ & $\mathrm{Y}$ & $\mathrm{X}$ & yield/\% \\
\hline 1 & $\mathrm{Me}$ & $\mathrm{CH}_{2}$ & $\mathrm{Br}$ & $41(83)^{19}$ & 11 & $\mathrm{Me}$ & $\mathrm{CH}_{2}$ & $\mathrm{Br}$ & \\
\hline 2 & $\mathrm{Me}$ & $\left(\mathrm{CH}_{2}\right)_{2}$ & $\mathrm{Br}$ & $67(90)^{19}$ & 12 & $\mathrm{Me}$ & $\left(\mathrm{CH}_{2}\right)_{2}$ & $\mathrm{Br}$ & 84 \\
\hline 3 & $\mathrm{Me}$ & $\left(\mathrm{CH}_{2}\right)_{3}$ & $\mathrm{Br}$ & $60(70)^{20}$ & 13 & $\mathrm{Me}$ & $\left(\mathrm{CH}_{2}\right)_{3}$ & $\mathrm{Br}$ & 80 \\
\hline 4 & $\mathrm{Me}$ & $\mathrm{CHPh}$ & $\mathrm{Br}$ & 42 & 14 & $\mathrm{Me}$ & $\mathrm{CHPh}$ & $\mathrm{Br}$ & \\
\hline 5 & Et & $\mathrm{CH}_{2}$ & $\mathrm{Br}$ & $78(80)^{21}$ & 15 & Et & $\mathrm{CH}_{2}$ & $\mathrm{Br}$ & 65 \\
\hline $6 a$ & $\mathrm{Bn}$ & $\mathrm{CH}_{2}$ & $\mathrm{Br}$ & $64(78)^{22}$ & $16 a$ & $\mathrm{Bn}$ & $\mathrm{CH}_{2}$ & $\mathrm{Br}$ & 79 \\
\hline $6 b$ & $\mathrm{Bn}$ & $\mathrm{CH}_{2}$ & $\mathrm{Cl}$ & 59 & $16 b$ & $\mathrm{Bn}$ & $\mathrm{CH}_{2}$ & $\mathrm{Cl}$ & 44 \\
\hline $7 a$ & ${ }^{t} \mathrm{Bu}$ & $\mathrm{CH}_{2}$ & $\mathrm{Br}$ & $44(79)^{19}$ & $17 a$ & ${ }^{t} \mathrm{Bu}$ & $\mathrm{CH}_{2}$ & $\mathrm{Br}$ & 83 \\
\hline $7 \mathbf{b}$ & ${ }^{t} \mathrm{Bu}$ & $\mathrm{CH}_{2}$ & $\mathrm{Cl}$ & 35 & $17 b$ & ${ }^{t} \mathrm{Bu}$ & $\mathrm{CH}_{2}$ & $\mathrm{Cl}$ & 90 \\
\hline $8 a$ & Mes & $\mathrm{CH}_{2}$ & $\mathrm{Br}$ & $84(68)^{19}$ & $18 a$ & Mes & $\mathrm{CH}_{2}$ & $\mathrm{Br}$ & 82 \\
\hline $8 b$ & Mes & $\mathrm{CH}_{2}$ & $\mathrm{Cl}$ & $53(76)^{23}$ & $18 b$ & Mes & $\mathrm{CH}_{2}$ & $\mathrm{Cl}$ & 86 \\
\hline 9 & Mes & $\left(\mathrm{CH}_{2}\right)_{2}$ & $\mathrm{Br}$ & $68(45)^{24}$ & 19 & Mes & $\left(\mathrm{CH}_{2}\right)_{2}$ & $\mathrm{Br}$ & 68 \\
\hline $10 a$ & Ad & $\mathrm{CH}_{2}$ & $\mathrm{Br}$ & $61(67)^{19}$ & $20 a$ & Ad & $\mathrm{CH}_{2}$ & $\mathrm{Br}$ & 85 \\
\hline $10 b$ & Ad & $\mathrm{CH}_{2}$ & $\mathrm{Cl}$ & 59 & $20 b$ & Ad & $\mathrm{CH}_{2}$ & $\mathrm{Cl}$ & 63 \\
\hline
\end{tabular}


Scheme 3. Preparation of Dicarbene Iron(II) Dihalide Complexes from Bis(imidazolium) Salts

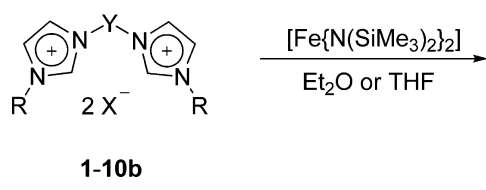

similar $\mathrm{C}-\mathrm{H} \cdots \mathrm{Br}$ interactions and with related bis(imidazolium) salt derivatives. ${ }^{25,26}$

Synthesis of Dicarbene Iron(II) Complexes 11-20. A suspension of the respective bis(imidazolium) salt in $\mathrm{Et}_{2} \mathrm{O}$ or THF is treated with $\left[\mathrm{Fe}\left\{\mathrm{N}\left(\mathrm{SiMe}_{3}\right)_{2}\right\}_{2}\right]_{2}$, and the ferrous $\mathrm{NHC}$ complex precipitates during the reaction (Scheme 3). Filtration and rinsing affords the desired product as a white to brownish powder, usually in around $80 \%$ yield. The yields of 11, 14, 15, and $\mathbf{1 6} \mathbf{b}$ are derogated by tetracarbene complex byproduct formation (see below); in the case of $\mathbf{1 1}$ no pure material could be isolated. In some cases further purification was hampered by the low solubility and limited stability in solution. The solid complexes 12-15 are quite air sensitive, and complexes 16 and 17 decompose within a couple of minutes up to $1 \mathrm{~h}$ in air, while complexes 18-20 with sterically demanding substituents (Mes and Ad) are air stable for several hours. In solution all these NHC complexes quickly decompose in the presence of air.

The solubility of the new dicarbene iron(II) dihalide complexes in nonpolar solvents is generally poor, while polar and particularly protic solvents induce decomposition. They are insoluble in alkanes and toluene, sparingly soluble in DCM and THF, and soluble but slowly decompose in $\mathrm{MeCN}, \mathrm{DMF}$, and DMSO. Complexes with bis(imidazolylidene) ligands bearing mesityl and benzyl substituents (16a,b, 18a,b, and 19) represent exceptions, since they show better solubility in DCM. Bulk crystallization from DCM, $\mathrm{CHCl}_{3}, \mathrm{THF}$, and dioxane in most cases was not successful; only 19 recrystallizes from DCM. Appending a phenyl group at the backbone methylene bridge (14) slightly increases the solubility. A similar effect was also observed for tetracarbene complexes $\mathbf{2 1}$ (insoluble in DCM) and 22 (phenyl substituted, soluble in DCM; see below). As a consequence, the purification and characterization of almost all dicarbene iron(II) complexes 1120 is limited by the poor solubility or stability in solution. However, the purity of most complexes after filtration, rinsing, and evaporation of the remaining solvents was quite good, as indicated by elemental analysis (EA) and Mössbauer spectroscopy ( $\mathrm{MB}$, see below).

Spectroscopic, Electrochemical, and Magnetic Characterization of Complexes 12-20. From the series of new dicarbene iron(II) dihalide complexes the molecular structures of $14,15,16 b, 17 a, 18 a$, and 19 were determined by X-ray diffraction. All complexes were characterized by EI-MS, MB, and EA (except for 11, 14, and 17b, which contained significant amounts of impurities). Those complexes soluble in DCM (17a, 18a,b, and 19) were additionally characterized by ${ }^{1} \mathrm{H}$ NMR and UV-vis spectroscopy.

${ }^{1} \mathrm{H}$ NMR spectra of $17 \mathbf{a}$ in DMSO- $d_{6}$ and $18 \mathbf{a}, \mathbf{b}$ and 19 in $\mathrm{CD}_{2} \mathrm{Cl}_{2}$ showed broad signals in the range of -5 to $60 \mathrm{ppm}$. Except for the ${ }^{1} \mathrm{H}$ NMR spectrum of $18 \mathrm{a}$, the number of signals and their integrals did not match expectations, likely due to paramagnetic broadening beyond detection for some signals. Paramagnetic signal broadening also prevented reasonable ${ }^{13} \mathrm{C}$ NMR measurements; hence, $\mathrm{C}-\mathrm{H}$ correlation experiments

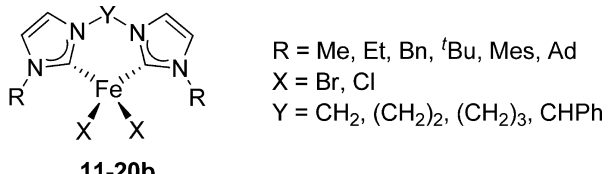

$11-20 b$

were not carried out. Cyclic voltammetry was performed for 17a, 18a,b, and 19 in MeCN or DCM (Table 2). All these

Table 2. Electrochemical Data for Selected Complexes ${ }^{a}$

$\begin{array}{cccl}\text { complex } & E_{\mathrm{p}}{ }^{\mathrm{a}} & E_{\mathrm{p}}{ }^{\mathrm{c}} & \text { solvent } \\ \mathbf{1 7 a} & +1.11 & -1.74 & \mathrm{MeCN} \\ \mathbf{1 8 a} & +1.06 & & \mathrm{DCM} \\ \mathbf{1 8 b} & +1.48 & -0.73 & \mathrm{MeCN} \\ \mathbf{1 9} & +1.07 & -1.99 & \mathrm{DCM}\end{array}$

${ }^{a}$ Peak potentials of irreversible processes in $\mathrm{V}$ vs NHE at $100 \mathrm{mV} / \mathrm{s}$.

complexes show irreversible processes in both oxidation and reduction. The first oxidation (anodic peak potential $E_{\mathrm{p}}{ }^{\mathrm{a}}$ ) is observed at around $+1.1 \mathrm{~V}$ vs $\mathrm{NHE}$ for several $\left[\mathrm{LFeBr}_{2}\right]$ complexes (the cyclic voltammogram of $\mathbf{1 7} \mathbf{a}$ is shown in Figure $\mathrm{S} 1$ (Supporting Information) as an example), but at $+1.48 \mathrm{~V}$ for chloride complex 18b. Apparently the corresponding ferric complexes are unstable or major structural changes occur upon oxidation of the ferrous complexes. We also tried to synthesize the corresponding dicarbene iron(III) species directly when using $8 \mathbf{a}$ and $\left[\mathrm{Fe}\left\{\mathrm{N}\left(\mathrm{SiMe}_{3}\right)_{2}\right\}_{3}\right]$ instead of $\left[\mathrm{Fe}\left\{\mathrm{N}\left(\mathrm{SiMe}_{3}\right)_{2}\right\}_{2}\right]_{2}$, but it was not possible to identify or isolate any dicarbene iron(III) complex. Instead, reduction occurred and iron(II) NHC complex 18a crystallized from the reaction mixture at $-30{ }^{\circ} \mathrm{C}$. These observations suggest that the potential dicarbene iron(III) halide species are not accessible, in accordance with electrochemical findings.

Mössbauer spectroscopy of complexes 12, 13, and 15-20 at $80 \mathrm{~K}$ showed isomer shifts of $0.73-0.81 \mathrm{~mm} \mathrm{~s}^{-1}$ and large quadrupole splittings in the range $3.67-4.03 \mathrm{~mm} \mathrm{~s}^{-1}$ (Table 3),

Table 3. Mössbauer Parameters of Selected Dicarbene Iron(II) Complexes at $80 \mathrm{~K}$

\begin{tabular}{cccc} 
complex & $\delta\left(\mathrm{mm} \mathrm{s}^{-1}\right)$ & $\Delta E_{Q}\left(\mathrm{~mm} \mathrm{~s}^{-1}\right)$ & $\Gamma\left(\mathrm{mm} \mathrm{s}^{-1}\right)$ \\
\hline $\mathbf{1 2}$ & 0.73 & 3.94 & 0.28 \\
13 & 0.74 & 3.75 & 0.27 \\
15 & 0.74 & 3.96 & 0.26 \\
16a & 0.73 & 3.93 & 0.26 \\
16b & 0.74 & 3.96 & 0.29 \\
17a & 0.79 & 3.78 & 0.31 \\
17b & 0.80 & 3.87 & 0.29 \\
18a & 0.74 & 4.03 & 0.26 \\
18b & 0.77 & 3.88 & 0.27 \\
19 & 0.77 & 3.91 & 0.26 \\
20a & 0.81 & 3.67 & 0.26 \\
20b & 0.78 & 3.79 & 0.28 \\
\hline
\end{tabular}

which is at the upper end of the $3-4 \mathrm{~mm} \mathrm{~s}^{-1}$ range typical for high-spin iron(II) in a tetrahedral environment $(S=2){ }^{26 \mathrm{~b}, 27}$ This comparison refers to iron complexes with thiourea or thiolate ligands, since Mössbauer data of tetrahedral iron NHC complexes are scarce. ${ }^{10 \mathrm{~g}}$ The high-spin state $(S=2)$ was further corroborated by a SQUID measurement of $18 \mathrm{a}$, giving $\mu_{\text {eff }}=5.1$ $\mu_{\mathrm{B}}$ (Figure 1). Mössbauer spectra of all iron complexes with bromide ligands show rough backgrounds due to a strong 

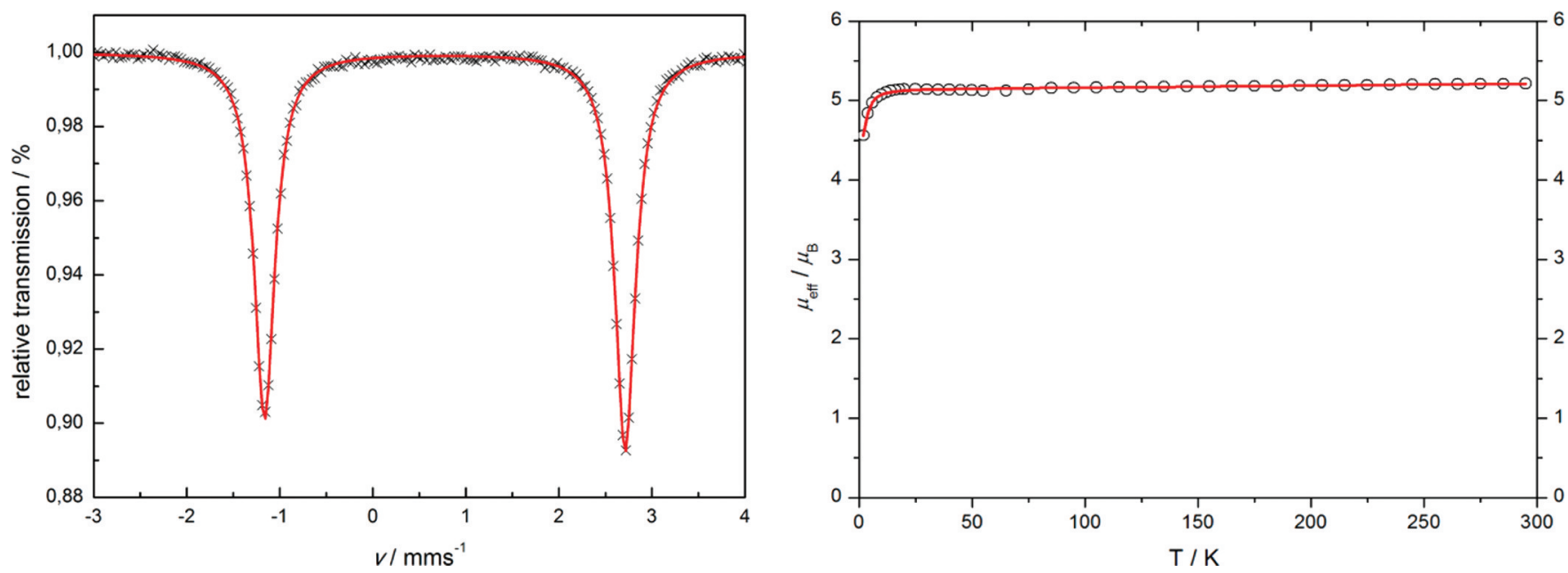

Figure 1. Mössbauer spectra of $\mathbf{1 8 b}$ at $80 \mathrm{~K}$ (left) and SQUID data for $\mathbf{1 8 a}$ at $0.5 \mathrm{~T}$ (right). The solid lines represent the calculated curve fits.

absorption of $\gamma$ radiation by bromine. According to Mössbauer spectroscopy most of the new complexes did not contain any or less than 5\% iron impurities.

Solid-State Structures. Single crystals of 14 were obtained by cooling a DCM solution to $-30{ }^{\circ} \mathrm{C}$. Complex 15 was crystallized by slow evaporation of pentane into a DCM solution at $8{ }^{\circ} \mathrm{C}$. A few tiny single crystals of $17 \mathrm{a}$ were obtained by crystallization from hot $\mathrm{MeCN}$ solution; this method is not convenient for bulk recrystallization, however, since most of the dicarbene iron complex decomposes. 18a crystallized from the reaction mixture of $8 \mathbf{a}$ and $\mathrm{Fe}\left[\mathrm{N}\left(\mathrm{SiMe}_{3}\right)_{2}\right]_{3}$ in $\mathrm{THF}$ at $-30{ }^{\circ} \mathrm{C}$. Complexes $16 \mathrm{~b}$ and 19 were crystallized by slow evaporation of pentane into a THF solution at $8{ }^{\circ} \mathrm{C}$. Molecular structures are shown in Figures 2-5 and Figures S4 and S5

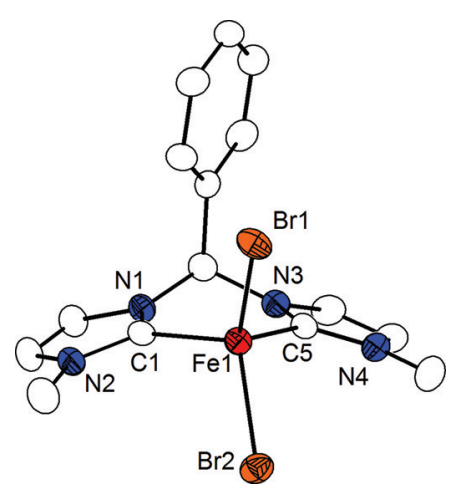

Figure 2. ORTEP plot ( $50 \%$ probability thermal ellipsoids) of the molecular structure of $\mathbf{1 4}$. Hydrogen atoms and solvent molecules have been omitted for clarity. Selected bond lengths $(\AA)$ and angles $(\mathrm{deg}): \mathrm{Fe} 1-\mathrm{C} 1=2.093(4), \mathrm{Fe} 1-\mathrm{C} 5=2.093(4), \mathrm{Fe} 1-\mathrm{Br} 1=$ 2.4095(6), $\mathrm{Fe} 1-\mathrm{Br} 2=2.4274(6) ; \mathrm{C} 1-\mathrm{Fe} 1-\mathrm{C} 5=89.18(14), \mathrm{C} 1-$ $\mathrm{Fe} 1-\mathrm{Br} 1=115.88(10), \mathrm{C} 5-\mathrm{Fe} 1-\mathrm{Br} 1=113.86(10), \mathrm{C} 1-\mathrm{Fe} 1-\mathrm{Br} 2=$ 111.80(10), C5-Fe1-Br2 = 109.10(10), Br1-Fe1-Br2 = 114.34(2).

(Supporting Information). Complex 17a crystallizes in the orthorhombic space group $P 2_{1} 2_{1} 2_{1}$; the other five complexes crystallize in the monoclinic space groups $P 2_{1}$ (18a), $P 2_{1} / n$ (14, $15)$, and $P 2_{1} / c(16 b, 19)$. In all complexes the iron atom is coordinated by the chelating NHC ligand and two halides in a distorted-tetrahedral geometry. The average iron-carbon distances of around $2.10 \AA$ are in good agreement with $\mathrm{Fe}-\mathrm{C}$ bond lengths of other tetrahedral bis(imidazolylidene) iron complexes; ${ }^{3 a, d}$ only in $17 \mathbf{a}$, bearing bulky tert-butyl substitutents, are they slightly longer $(2.13 \AA)$, presumably for steric reasons. In complexes with methylene-bridged bis(imidazolylidene) ligands, the six-membered chelate rings adopt a distorted boatlike conformation. $\mathrm{X}-\mathrm{Fe}-\mathrm{X}$ $(\mathrm{X}=\mathrm{Cl}, \mathrm{Br})$ and $\mathrm{C}-\mathrm{Fe}-\mathrm{C}$ angles are wider for $\mathrm{X}=\mathrm{Br}$ than for $\mathrm{X}=\mathrm{Cl}$ due to the larger atom radius of bromide; the $\mathrm{C}-\mathrm{Fe}-\mathrm{C}$ angle furthermore depends on the peripheral NHC substituents

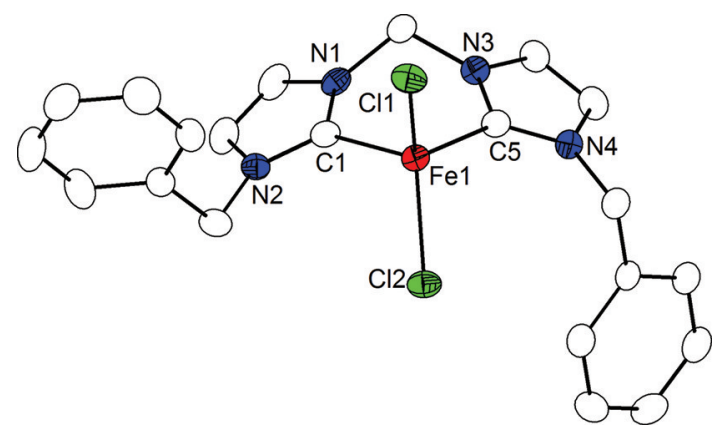

Figure 3. ORTEP plot ( $50 \%$ probability thermal ellipsoids) of the molecular structure of $\mathbf{1 6 b}$. Hydrogen atoms have been omitted for clarity. Selected bond lengths $(\AA)$ and angles (deg): Fe1-C1 = 2.107(3), Fe1-C5 = 2.111(3), Fe1-Cl2 = 2.2631(9), Fe1-Cl1 = 2.2769(8); C1-Fe1-C5 = 88.45(11), C1-Fe1-Cl2 = 114.38(8), $\mathrm{C} 5-\mathrm{Fe} 1-\mathrm{Cl} 2=114.61(9), \mathrm{C} 1-\mathrm{Fe} 1-\mathrm{Cl} 1=111.30(8), \mathrm{C} 5-\mathrm{Fe} 1-\mathrm{Cl} 1=$ $115.35(8), \mathrm{Cl} 2-\mathrm{Fe} 1-\mathrm{Cl} 1=111.06(3)$.

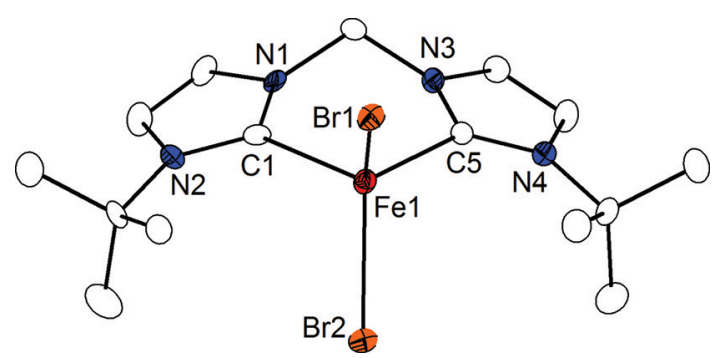

Figure 4. ORTEP plot ( $50 \%$ probability thermal ellipsoids) of the molecular structure of $17 \mathbf{a}$. Hydrogen atoms have been omitted for clarity. Selected bond lengths ( $\AA$ ) and angles (deg): Fe1-C5 = 2.126(6), $\mathrm{Fe} 1-\mathrm{C} 1=2.128(6), \mathrm{Fe} 1-\mathrm{Br} 1=2.4490(9), \mathrm{Fe} 1-\mathrm{Br} 2=$ $2.4549(10) ; \mathrm{C} 5-\mathrm{Fe} 1-\mathrm{C} 1=95.6(2), \mathrm{C} 5-\mathrm{Fe} 1-\mathrm{Br} 1=113.57(14)$, $\mathrm{C} 1-\mathrm{Fe} 1-\mathrm{Br} 1=112.03(15), \mathrm{C} 5-\mathrm{Fe} 1-\mathrm{Br} 2=106.17(15), \mathrm{C} 1-\mathrm{Fe} 1-$ $\mathrm{Br} 2=105.15(15), \mathrm{Br} 1-\mathrm{Fe} 1-\mathrm{Br} 2=121.02(4)$. 


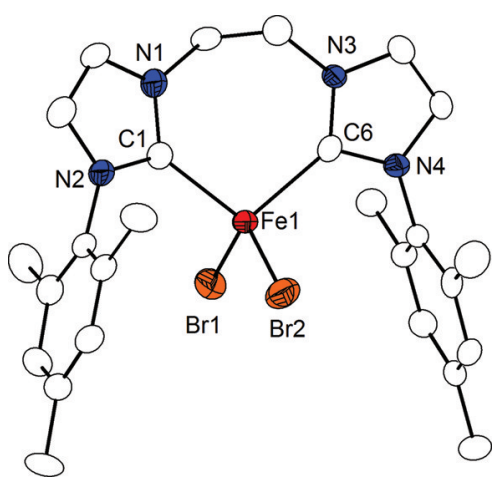

Figure 5. ORTEP plot ( $50 \%$ probability thermal ellipsoids) of the molecular structure of $\mathbf{1 9}$. Hydrogen atoms and the solvent molecule have been omitted for clarity. Selected bond lengths $(\AA)$ and angles $(\mathrm{deg}): \mathrm{Fe} 1-\mathrm{C} 1=2.100(6), \mathrm{Fe} 1-\mathrm{C} 6=2.108(5), \mathrm{Fe} 1-\mathrm{Br} 2=$ 2.4410(11), $\mathrm{Fe} 1-\mathrm{Br} 1=2.4433(11) ; \mathrm{C} 1-\mathrm{Fe} 1-\mathrm{C} 6=103.7(2), \mathrm{C} 1-$ $\mathrm{Fe} 1-\mathrm{Br} 2=106.95(16), \mathrm{C} 6-\mathrm{Fe} 1-\mathrm{Br} 2=106.08(14), \mathrm{C} 1-\mathrm{Fe} 1-\mathrm{Br} 1=$ 109.62(16), C6-Fe1-Br1 = 110.72(16), Br2-Fe1-Br1 = 118.66(4).

(Table 4). In case of the ethylene bridge (19) the $\mathrm{C}-\mathrm{Fe}-\mathrm{C}$ angle is found to be the largest in this series $\left(103.7^{\circ}\right)$.

Synthesis and Characterization of Tetracarbene Iron(II) Complexes. When bis(imidazolium) salts that have small $(\mathrm{Me}, \mathrm{Et})$ substituents are reacted with $\left[\mathrm{Fe}\left\{\mathrm{N}\left(\mathrm{SiMe}_{3}\right)_{2}\right\}_{2}\right]_{2}$, octahedral tetracarbene iron(II) complexes are formed as a byproduct in addition to the desired dicarbene iron(II) complexes, giving the otherwise white suspension a distinct color (21, red; 22, green; 23, yellow; Scheme 4). Due to the similar solubilities of di- and tetracarbene complexes, their separation and isolation proved difficult. Dicarbene 11 and tetracarbene 21, for example, precipitate as a mixture during the reaction, but neither of them was found to be soluble in any solvent without either ligand exchange or decomposition; therefore, they could not be separated and characterized. In the case of 22 separation was achieved, although no analytically pure bulk material could be obtained. Instead, the identity of the related tetracarbene complexes 24-26 was elucidated by Xray diffraction of single crystals that grew upon slow diffusion of $\mathrm{Et}_{2} \mathrm{O}$ into $\mathrm{MeCN}$ solutions of the crude products 21-23.

It was found that complexes 21-23 exchange both bromide ligands upon treatment with acetonitrile, leading to the tetracarbene iron(II) salts $\left[\mathrm{L}_{2} \mathrm{Fe}(\mathrm{MeCN})_{2}\right]\left[\mathrm{FeBr}_{4}\right]$ (24-26). The tetrabromoferrate(II) anion is formed from the two bromide ions and residual solvated $\mathrm{FeBr}_{2}$. The behavior of 14 in DCM solution suggests that this dicarbene complex may be in dynamic equilibrium with the corresponding tetracarbene complex 22 and $\left[\mathrm{FeBr}_{2}(\mathrm{solv})_{x}\right]$ via bis(imidazolylidene) ligand transmetalation. The position of the equilibrium seems to depend on solvent, concentration and temperature. In $\mathrm{MeCN}$ the driving force supposably is irreversible $\left[\mathrm{L}_{2} \mathrm{Fe}(\mathrm{MeCN})_{2}\right]$ $\left[\mathrm{FeBr}_{4}\right]$ salt formation. Bis(imidazolium) salts with benzyl residues $(\mathbf{6 a}, \mathbf{b})$ are flexible enough to also form tetracarbene complexes upon reaction with $\left[\mathrm{Fe}\left\{\mathrm{N}\left(\mathrm{SiMe}_{3}\right)_{2}\right\}_{2}\right]_{2}$ in THF, but in lower amounts compared to those of 1, 4, and 5. ESI-MS confirmed the formation of tetracarbene iron(II) complexes when 11 and 14-16 were treated with MeCN. In the Mössbauer spectrum of 24 (Figure 6) signals for both the tetracarbene dication (low-spin (ls) iron(II) with $\delta=0.15 \mathrm{~mm} \mathrm{~s}^{-1}, \Delta E_{\mathrm{Q}}=$ $1.36 \mathrm{~mm} \mathrm{~s}^{-1}, \Gamma=0.38 \mathrm{~mm} \mathrm{~s}^{-1}$ ) and the tetrabromoferrate(II) anion (high-spin (hs) iron(II) with $\delta=1.05 \mathrm{~mm} \mathrm{~s}^{-1}, \Delta E_{\mathrm{Q}}=2.88$ $\left.\mathrm{mm} \mathrm{s}^{-1}, \Gamma=0.51 \mathrm{~mm} \mathrm{~s}^{-1}\right)^{28}$ are found. ${ }^{29}$ NMR measurements were hampered by the paramagnetic tetrabromoferrate(II), though the tetracarbene complex itself is diamagnetic. Attempts to exchange the $\left[\mathrm{FeBr}_{4}\right]^{2-}$ for $\mathrm{PF}_{6}{ }^{-}$or $\mathrm{BF}_{4}{ }^{-}$have failed so far.

The molecular structures of 24-26 (Figure 7 and Figures S6 and S7 (Supporting Information)) were determined by X-ray diffraction. In all cases yellow single crystals could be grown by slow diffusion of $\mathrm{Et}_{2} \mathrm{O}$ into $\mathrm{MeCN}$ solutions of the complexes. 24 crystallizes in the monoclinic space group $P 2_{1} / m, 25$ in triclinic $P \overline{1}$, and 26 in orthorhombic Ama2. All three complexes exhibit very similar structural parameters. The iron(II) ion is found in an octahedral environment, with the coordination sphere composed of two bis(imidazolylidene) ligands and two acetonitrile molecules in a cis configuration. The $\left[\mathrm{FeBr}_{4}\right]^{2-}$ counteranion is associated with the NHC complex cation by two or more $\mathrm{C}-\mathrm{H} \cdots \mathrm{Br}$ hydrogen bonds.

$\mathrm{Fe}-\mathrm{C}$ distances trans to $\mathrm{MeCN}$ ligands are in the range 1.92$1.95 \AA$, while those trans to another NHC moiety are in the range 1.96-1.99 $\AA$, reflecting the strong NHC trans influence. These bond lengths are slightly longer than $\mathrm{Fe}-\mathrm{C}$ distances (1.90-1.96 A) reported for octahedral tetracarbene iron complexes with two tridentate $\{\mathrm{CNC}\}$ donor ligands (bis(imidazolylidene)pyridine iron(II) complexes). ${ }^{9 \mathrm{a}, \mathrm{b}} \mathrm{Fe}-\mathrm{C}$ distances of $1.99-2.00 \AA$ were previously found in hexacarbene iron(II) complexes. $^{10 \mathrm{a}, \mathrm{b}}$ In comparison to $\mathrm{Fe}-\mathrm{C}$ distances of the dicarbene iron(II) complexes discussed above (2.09-2.13 $\AA$ ), bond lengths in 24-26 are 0.11-0.18 $\AA$ shorter, since the iron(II) ion is in its low-spin state and anionic ligands (halides) are absent. $\mathrm{C}-\mathrm{Fe}-\mathrm{C}$ and $\mathrm{C}-\mathrm{Fe}-\mathrm{N}$ angles of trans-standing ligands are found in the range $172.6-179.2^{\circ}$, thus indicating only slight distortion from octahedral geometry for all three complexes 24-26.

Cross-Coupling Catalysis. Transition-metal-catalyzed Grignard cross-coupling reactions have become a well-established $\mathrm{C}-\mathrm{C}$ coupling method in recent years. ${ }^{30,31}$ The Kumada-Curriu coupling of aryl Grignard reagents with primary or secondary alkyl halides is typically performed with $\mathrm{Ni}$ and $\mathrm{Pd}$ catalysts. ${ }^{32,33}$ Due to economical and environmental aspects, however, ironcatalyzed cross-coupling reactions have become an attractive alternative. Inspired by the work of Kochi et al., ${ }^{34}$ several groups have reported iron-based catalysts that show good activities and surmount significant $\beta$-hydride elimination product formation, which is the main limitation if primary and especially secondary alkyl halides are used. ${ }^{4,8}$ In general, transition-metal complexes with NHC ligands have proven to be effective catalysts for $\mathrm{C}-\mathrm{C}$ coupling reactions. ${ }^{1,2}$ However, among the various iron(III) and

Table 4. Selected Bond Lengths and Angles of Several Dicarbene Iron(II) Dihalide Complexes

$\begin{array}{ccccccc}\text { complex } & \mathrm{X} & \phi(\mathrm{Fe}-\mathrm{C})(\AA) & \phi(\mathrm{Fe}-\mathrm{X})(\AA) & \mathrm{C}-\mathrm{Fe}-\mathrm{C}(\mathrm{deg}) & \mathrm{X}-\mathrm{Fe}-\mathrm{X}(\mathrm{deg}) & \mathrm{N}-\mathrm{CH} \mathrm{C}_{2}-\mathrm{N}(\mathrm{deg}) \\ \mathbf{1 4} & \mathrm{Br} & 2.093 & 2.418 & 89.18(14) & 114.34(2) & 120.42(3) \\ \mathbf{1 5} & \mathrm{Br} & 2.098 & 2.423 & 90.01(15) & 111.06(3) & 11.4(3) \\ \mathbf{1 6 b} & \mathrm{Cl} & 2.109 & 2.270 & 88.45(11) & 121.02(4) & 111.7(2) \\ \mathbf{1 7 a} & \mathrm{Br} & 2.127 & 2.452 & 95.6(2) & 117.56(2) & 114.1(4) \\ \mathbf{1 8 a} & \mathrm{Br} & 2.113 & 2.407 & 87.42(12) & 118.66(4)\end{array}$


Scheme 4. Formation of Tetracarbene Iron(II) Complexes

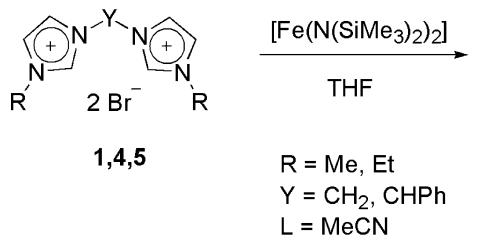

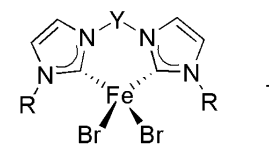

$11,14,15$

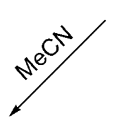

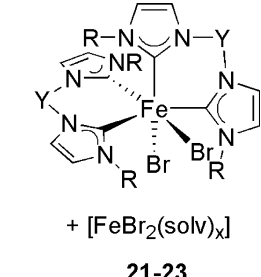

21-23

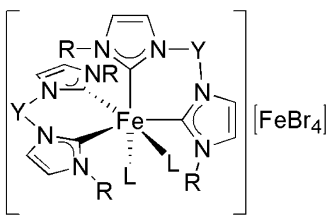

21, $24 \mathrm{R}=\mathrm{Me}, \mathrm{Y}=\mathrm{CH}_{2}$

22, $25 \mathrm{R}=\mathrm{Me}, \mathrm{Y}=\mathrm{CHPh}$

23, $26 \mathrm{R}=\mathrm{Et}, \mathrm{Y}=\mathrm{CH}_{2}$

24-26

iron(II) catalysts tested in aryl Grignard-alkyl halide crosscoupling reactions, only two well-defined systems with NHC ligands have yet been reported: namely, the pyridyl bis(carbene) pincer complex by Bedford et al. ${ }^{8 \mathrm{~g}}$ and a monodentate NHC complex by Gao et al. ${ }^{4}$ Both complexes, as well as some in situ generated iron NHC catalysts, showed above $90 \%$ conversion to the coupled product. These findings motivated preliminary studies on the catalytic activity of selected examples of the new dicarbene iron complexes reported herein that contain potentially more rugged bidentate NHC chelate ligands.

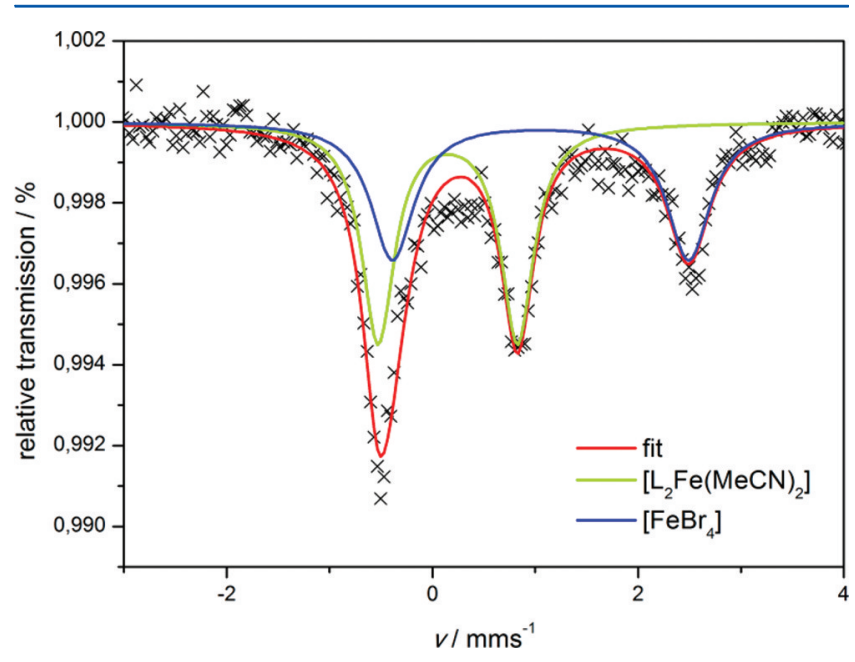

Figure 6. Mössbauer spectrum of 24 at $80 \mathrm{~K}^{29}$

The cross-coupling reaction of $p$-tolylmagnesium bromide with bromo- or chlorocyclohexane (Scheme 5) was chosen as a test reaction because it is a common benchmark example of an aryl Grignard-secondary alkyl halide coupling. The reaction may lead to up to five products $(\mathbf{I}-\mathbf{V}){ }^{8 \mathrm{~d}, \mathrm{~g}}$ By NMR only heterocoupled product I and homocoupled product II could be identified in the product mixtures. The formation of trace amounts of byproducts III-V was detected by GC/MS of the organic phase after workup; but only for runs in THF and runs with chlorocyclohexane are the amounts of III-V nonnegligible. Initial screening of the reaction conditions (solvent, temperature, duration) led to the same favourable procedure that is commonly followed for most aryl Grignard-alkyl halide couplings $\left(\mathrm{Et}_{2} \mathrm{O}\right.$, reflux, $\left.0.5 \mathrm{~h}\right)$. $^{4,8 c, \mathrm{~d}}$
All of the studied iron NHC complexes mediate the coupling reaction (Table 5), albeit with clearly different catalytic activities. In the case of complexes 17a and 20a, which are insoluble in $\mathrm{Et}_{2} \mathrm{O}$, reactions were performed in THF instead, but this led to higher amounts of $\beta$-hydride elimination product (IV), hydrodehalogenation product (V), and homocoupling product (II) (entries 9 and 10).

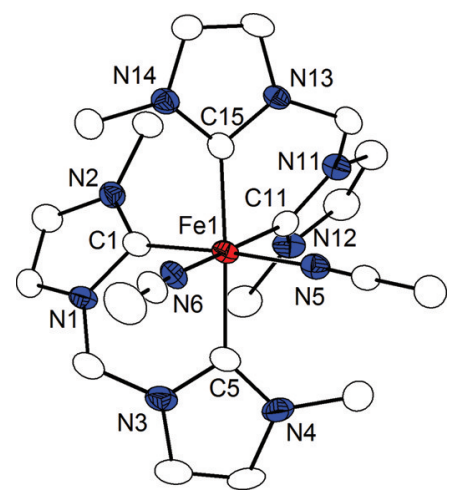

Figure 7. ORTEP plot ( $40 \%$ probability thermal ellipsoids) of the molecular structure of $\mathbf{2 4}$. Hydrogen atoms, solvent molecules, and the $\left[\mathrm{FeBr}_{4}\right]^{2-}$ counterion have been omitted for clarity. Selected bond lengths $(\AA)$ and angles (deg): Fe1-C1 = 1.931(5), Fe1-C11 = $1.938(5), \mathrm{Fe} 1-\mathrm{C} 15=1.965(5), \mathrm{Fe} 1-\mathrm{N} 5=1.972(5), \mathrm{Fe} 1-\mathrm{N} 6=$ 1.983(4), Fe1-C5 = 1.986(5); C1-Fe1-C11 = 90.4(2), C1-Fe1$\mathrm{C} 15=91.5(2), \mathrm{C} 11-\mathrm{Fe} 1-\mathrm{C} 15=86.9(2), \mathrm{C} 1-\mathrm{Fe} 1-\mathrm{N} 5=176.4(2)$, $\mathrm{C} 11-\mathrm{Fe} 1-\mathrm{N} 5=90.52(19), \mathrm{C} 15-\mathrm{Fe} 1-\mathrm{N} 5=91.99(19), \mathrm{C} 1-\mathrm{Fe} 1-$ $\mathrm{N} 6=96.09(19), \mathrm{C} 11-\mathrm{Fe} 1-\mathrm{N} 6=172.54(19), \mathrm{C} 15-\mathrm{Fe} 1-\mathrm{N} 6=$ 89.30(19), N5-Fe1-N6 = 83.22(17), C1-Fe1-C5 = 86.6(2), C11$\mathrm{Fe} 1-\mathrm{C} 5=94.5(2), \mathrm{C} 15-\mathrm{Fe} 1-\mathrm{C} 5=177.6(2), \mathrm{N} 5-\mathrm{Fe} 1-\mathrm{C} 5=$ 89.94(19), N6-Fe1-C5 = 89.6(2).

The highest activity was found for complex 19 with $75 \%$ conversion at $5 \mathrm{~mol} \%$ catalyst loading (entry 4). Reduction of the loading to $1 \mathrm{~mol} \%$ went along with a decreased conversion of $66 \%$. In situ generation of 19 by the reaction of $\mathrm{FeBr}_{2}$ with bis(imidazolium) salt 9 in the presence of $p$-tolylmagnesium bromide surprisingly led to slightly higher conversion of $79 \%$ (entry 3). Other dicarbene complexes as well as catalysts generated in situ from bis(imidazolium) salts and $\mathrm{FeBr}_{2}$ were tested, but none of them outperformed precatalyst 19. It should be noted that 19 features the most shielded metal center of the present series of dicarbene complexes, because of the long 
Scheme 5. Transition-Metal-Catalyzed Reaction between Bromo- or Chlorocyclohexane and $p$-Tolylmagnesium Bromide

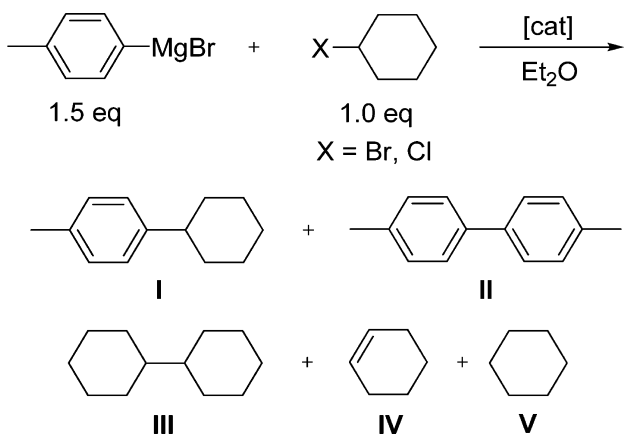

ethylene linker between the two imidazolylidene groups and the bulky Mes substituents. Formation of the homocoupled product II was usually found in the range of $5-8 \%$. $\left[\mathrm{FeBr}_{2}(\text { thf })_{2}\right]$ (entry 2) was used for comparison, giving $69 \%$ conversion to $\mathrm{I}$; simple $\mathrm{FeBr}_{2}$ was previously reported to yield $41 \%$ conversion under identical conditions. ${ }^{4}$ In addition to bromocyclohexane, the less reactive chlorocyclohexane was also used as substrate (entries 11-13). In this case the chlorideligated complex $\mathbf{1 8 b}$ did not give reasonable conversion (15\%), while catalyst 19 and the in situ generated analogue $\left(9+\mathrm{FeBr}_{2}\right)$ both provided conversions of around 60\%. However, in

Table 5. Iron-Catalyzed Coupling of Bromo- or Chlorocyclohexane with $p$-Tolylmagnesium Bromide ${ }^{a}$

\begin{tabular}{|c|c|c|c|c|}
\hline \multirow[b]{2}{*}{ entry } & \multirow[b]{2}{*}{ cat. } & \multirow[b]{2}{*}{$\begin{array}{l}\text { cat. loading } \\
(\mathrm{mol} \%)\end{array}$} & \multicolumn{2}{|c|}{$\begin{array}{c}\text { conversion to compd } \\
(\%)\end{array}$} \\
\hline & & & I & II \\
\hline $1^{4}$ & $\mathrm{FeBr}_{2}$ & 5 & 41 & \\
\hline 2 & $\mathrm{FeBr}_{2}(\text { thf })_{2}$ & 5 & 69 & 5 \\
\hline 3 & $\mathrm{FeBr}_{2}+9$ & $5+5$ & 79 & 8 \\
\hline 4 & 19 & 5 & 75 & 5 \\
\hline 5 & 19 & 1 & 66 & 6 \\
\hline 6 & 12 & 5 & 56 & 7 \\
\hline 7 & $18 a$ & 5 & 62 & 5 \\
\hline 8 & $16 a$ & 5 & 46 & 6 \\
\hline $9^{c}$ & $17 a$ & 5 & 30 & 15 \\
\hline $10^{c}$ & $20 a$ & 5 & 5 & 9 \\
\hline $11^{d}$ & $\mathrm{FeBr}_{2}+9$ & $5+5$ & 60 & 11 \\
\hline $12^{d}$ & 19 & 5 & 60 & 14 \\
\hline $13^{d}$ & $18 \mathrm{~b}$ & 5 & 15 & 5 \\
\hline
\end{tabular}

${ }^{a}$ Conditions: bromocyclohexane $(1.0 \mathrm{mmol}), p$-toluolmagnesium bromide $(1.5 \mathrm{mmol})$, catalyst, $\mathrm{Et}_{2} \mathrm{O}$, reflux, $30 \mathrm{~min} .{ }^{b}$ Conversion to products I and II determined by ${ }^{1} \mathrm{H}$ NMR (1,3,5-trimethoxybenzene as internal standard), average of two trials. ${ }^{c}$ Solvent THF; no conversion observed in $\mathrm{Et}_{2} \mathrm{O}$ for these complexes, due to insolubility. ${ }^{d}$ Chlorocyclohexane used instead of bromocyclohexane.

contrast to reactions with bromocyclohexane, considerably more homocoupled product II was generated.

Different views still exist about the mechanism of $\mathrm{Fe}$ catalyzed cross-coupling reactions. ${ }^{8 \mathrm{~g}, 31}$ Mechanistic proposals comprise oxidative addition/reductive elimination cycles with $\mathrm{Fe}$ shuttling between the $\mathrm{Fe}(0) / \mathrm{Fe}(\mathrm{II})$ or $\mathrm{Fe}(-\mathrm{II}) / \mathrm{Fe}(0)$ states, $^{35}$ as well as radical-based scenarios. ${ }^{8 a, b}$ In all cases the actual catalytic cycle is likely preceded by precatalyst reduction by the Grignard reagent to give the active iron species. Reports about the use of $\mathrm{Fe} / \mathrm{NHC}$ cross-coupling catalysts are still relatively rare, but some previously reported iron catalysts with 2 equiv of monodentate NHC ligands tested under similar conditions (catalysts prepared in situ from $\mathrm{FeBr}_{2}$ and 2 equiv of the respective imidazolium salt) showed somewhat higher activities than the new complexes investigated here. ${ }^{4}$ Possibly the constrained chelate arrangement of the present bis(imidazolylidene) ligands is less favorable for adapting to the different stereoelectronic requirements of iron in its various redox states during the catalytic cycle. Higher activity was also observed for the anionic $\left[\mathrm{Fe}(\mathrm{NHC}) \mathrm{Br}_{3}\right]^{-}$precatalyst, which was ascribed to the pronounced nucleophilicity of that species. ${ }^{4}$ It remains to be investigated, however, whether the NHC ligands indeed remain bound to the active $\mathrm{Fe}$ species during turnover, or whether other species (such as nanoparticulate $\mathrm{Fe}$ ) are formed.

\section{CONCLUSIONS}

An efficient synthesis of bis-chelate NHC iron(II) dihalide complexes $\left[\mathrm{LFeX}_{2}\right](\mathrm{X}=\mathrm{Cl}, \mathrm{Br})$ has been developed using $\left[\mathrm{Fe}\left\{\mathrm{N}\left(\mathrm{SiMe}_{3}\right)_{2}\right\}_{2}\right]_{2}$ as a basic precursor for in situ deprotonation of the respective bis(imidazolium) salts. Preferential tetracarbene complex formation was observed if the ligand bears small $(\mathrm{Me}, \mathrm{Et})$ or flexible $(\mathrm{Bn})$ substituents. Complexes $\left[\mathrm{L}_{2} \mathrm{FeX}_{2}\right]$ (in the presence of residual $\left[\mathrm{FeBr}_{2}(\text { solv })_{x}\right]$ ) transform into $\left[\mathrm{L}_{2} \mathrm{Fe}(\mathrm{MeCN})_{2}\right]\left[\mathrm{FeBr}_{4}\right]$ when dissolved in $\mathrm{MeCN}$. Molecular structures of several dicarbene $(14,15,16 \mathrm{~b}, 17 \mathrm{a}$, 18a, 19) and tetracarbene iron(II) complexes (24-26) as well as of the precursor bis(imidazolium) salt 4 have been determined crystallographically. Complex 19 was found to be the catalytically most active compound in a standard aryl Grignard-alkyl halide cross-coupling reaction, but activities are generally lower than previously reported activities of related complexes with two monodentate NHC ligands; in the previous work, however, precatalyst complexes usually had not been isolated and fully characterized. The new dicarbene iron(II) complexes reported here may be valuable starting materials for the synthesis of iron clusters and may be tested in further iron-mediated catalytic reactions. Work in that direction is in progress.

\section{EXPERIMENTAL SECTION}

General Considerations. Air-sensitive reactions were carried out under dry argon using standard Schlenk techniques, or in a glovebox (MBRAUN LabMaster) under a nitrogen atmosphere with less than $0.1 \mathrm{ppm}$ of $\mathrm{O}_{2}$ and $\mathrm{H}_{2} \mathrm{O}$. Solvents were dried and degassed by standard procedures before use. Bromocyclohexane and chlorocyclohexane were degassed and dried over molecular sieves; all other chemicals were purchased from commercial sources and used as received. Ethylimidazole (Et-Im), ${ }^{36}{ }^{t} \mathrm{Bu}-\mathrm{Im},{ }^{37} \mathrm{Bn}-\mathrm{Im},{ }^{38} \mathrm{Mes}-\mathrm{Im},{ }^{37} \mathrm{Ad}-\mathrm{Im},{ }^{37}$ and $\left[\mathrm{Fe}\left\{\mathrm{N}\left(\mathrm{SiMe}_{3}\right)_{2}\right\}_{2}\right]_{2}{ }^{17}$ were prepared according to published procedures. The bis(imidazolium) salts $\mathbf{1 - 3}, \mathbf{5}, \mathbf{6 a}, 7 \mathbf{a}, \mathbf{8 a}, \mathbf{9}$, and 10a were synthesized following the general procedure for methylenebridged imidazolium salts reported by Scherg et al. ${ }^{19}$ Spectral data for $3,{ }^{20} 5,{ }^{21} 6 a^{22} 8 b^{23}$ and $9^{24}$ were found as previously reported. ${ }^{1} \mathrm{H}$ and ${ }^{13} \mathrm{C}\left\{{ }^{1} \mathrm{H}\right\}$ NMR spectra were recorded on a Bruker Avance DRX 500 or Bruker Avance 300 spectrometer at $25{ }^{\circ} \mathrm{C}$; the chemical shifts $(\delta)$ are given in ppm relative to TMS. Mass spectrometry was performed with a Finnigan MAT 8200 (EI), an Applied Biosystems API 2000 (ESI), or a Bruker HCT ultra (ESI) instrument. UV-vis spectra were collected with a Varian Cary 50 Bio instrument using Schlenk quartz cuvettes. GC/MS spectra were measured on a Thermo Finnigan Trace GC using EI-MS. Melting points were determined in glass capillary tubes on a Stanford Research Systems OptiMelt MPA 100 device; values are 
uncorrected. Mössbauer (MB) spectra were recorded with a ${ }^{57} \mathrm{Co}$ source in a Rh matrix using an alternating constant-acceleration Wissel Mössbauer spectrometer operated in the transmission mode and equipped with a Janis closed-cycle helium cryostat. Isomer shifts $\delta$ are given in $\mathrm{mm} \mathrm{s}^{-1}$ relative to iron metal at ambient temperature. The quadrupole splitting $\Delta E_{\mathrm{Q}}$ and full width at half-maximum $\Gamma$ are given in $\mathrm{mm} \mathrm{s}^{-1}$. Simulation of the experimental data was performed with the Mfit program. ${ }^{39}$ Magnetic susceptibility measurements were carried out on a Quantum-Design MPMS-XL-5 SQUID magnetometer equipped with a $5 \mathrm{~T}$ magnet in the range $2-300 \mathrm{~K}$. The powdered samples were contained in a gel bucket and fixed in a nonmagnetic sample holder. Each raw data file for the measured magnetic moment was corrected for the diamagnetic contribution of the sample holder and the sample. Simulation of the experimental magnetic data was performed with the julX program. ${ }^{40}$ Elemental analyses were performed by the analytical laboratory of the Institute of Inorganic Chemistry at the Georg-August-University Göttingen using an Elementar Vario EL III instrument.

X-ray Diffraction. X-ray data were collected on a STOE IPDS II diffractometer (graphite-monochromated Mo $\mathrm{K} \alpha$ radiation, $\lambda=0.710$ $73 \AA$ ) by use of $\omega$ scans at $-140{ }^{\circ} \mathrm{C}$ (Tables S1 and S2, Supporting Information). The structures were solved by direct methods and refined on $F^{2}$ using all reflections with SHELX-97. ${ }^{41}$ Most nonhydrogen atoms were refined anisotropically. Most hydrogen atoms were placed in calculated positions and assigned to an isotropic displacement parameter of $0.08 \AA^{2}$. The positional and isotropic thermal parameters of the hydrogen atoms $\mathrm{H} 1, \mathrm{H} 4$, and $\mathrm{H} 5$ in 4 were refined freely. One of the $\left[\mathrm{FeBr}_{4}\right]^{2-}$ counterions and one $\mathrm{Et}_{2} \mathrm{O}$ solvent molecule in $\mathbf{2 4}$ were found to be disordered and therefore refined with half-occupancy. DFIX restraints $\left(d_{\mathrm{C}-\mathrm{C}}=1.51 \AA\right.$, $\left.d_{\mathrm{C}-\mathrm{O}}=1.42 \AA\right)$ were applied to model the disorder of the solvent molecule. All carbon and oxygen atoms of the disordered part were refined isotropically. The disorder of the two MeCN molecules in $\mathbf{2 5}$ was modeled by using SAME restraints (occupancy factors $0.39(3) / 0.61(3)$ and $0.57(3) /$ $0.43(3)$ ). All atoms of the disordered parts were refined isotropically. All $\mathrm{CH}_{2} \mathrm{Cl}_{2}$ solvent molecules in $\mathbf{1 4}$ are disordered and were refined using DFIX restraints $\left(d_{\mathrm{C}-\mathrm{Cl}}=1.79 \AA, d_{\mathrm{Cl} \cdots \mathrm{Cl}}=2.9 \AA\right)$ and EADP constraints. One $\mathrm{CH}_{2} \mathrm{Cl}_{2}$ was found to be disordered about a center of inversion and was refined with a fixed occupancy of 0.5 . The other solvent molecule was found to be disordered about two positions (occupancy factors: $0.490(3) / 0.510(3)$ ). The disordered parts of two THF solvent molecules in 18a were refined isotropically. The absolute structure parameters for $17 \mathbf{a}(0.021(16))$ and $26(0.020(10))$ were determined with SHELXL-97 according to Flack. ${ }^{42}$ Face-indexed absorption corrections were performed numerically with the program X-RED. ${ }^{43}$

General Procedure for the Synthesis of Methylene-Bridged Bis(imidazolium) Chlorides. A solution of the N-substituted imidazole $(25.0 \mathrm{mmol})$ in dichloromethane $(50 \mathrm{~mL})$ was stirred in a $100 \mathrm{~mL}$ ACE glass autoclave at $110{ }^{\circ} \mathrm{C}$ for 3 days. All volatiles were removed under reduced pressure. The residue was refluxed in $\mathrm{MeCN}$ $(50 \mathrm{~mL})$ for some minutes and cooled to room temperature. The precipitate was filtered off and washed with $\mathrm{MeCN}(2 \times 5 \mathrm{~mL})$. Evaporation of the solvent under high vacuum at $100-150{ }^{\circ} \mathrm{C}$ (below the melting point) yielded the bis(imidazolium) salt as a hygroscopic white powder. The synthesis was adapted from Scherg et al. ${ }^{19}$

Synthesis of Phenylbis(3-methylimidazolium-1-yl)methane Dibromide (4). A solution of 1-methylimidazole (5.00 g, $60.9 \mathrm{mmol}, 2.2$ equiv) and $\alpha, \alpha^{\prime}$-dibromotoluene $(6.92 \mathrm{~g}, 27.7 \mathrm{mmol})$ was dissolved in $\mathrm{MeCN}(60 \mathrm{~mL})$. The reaction mixture was heated to reflux for 2 days. Workup was performed as described in the general procedure. Yield: $4.80 \mathrm{~g}$ (11.6 mmol, 42\%). Colorless single crystals suitable for X-ray diffraction were grown by slow diffusion of $\mathrm{Et}_{2} \mathrm{O}$ into a $\mathrm{MeCN}$ solution.

${ }^{1} \mathrm{H}$ NMR (300 MHz, DMSO- $\left.d_{6}\right): \delta 9.44(\mathrm{~s}, 2 \mathrm{H}, \mathrm{NCHN}), 8.61(\mathrm{~s}$, $1 \mathrm{H}, \mathrm{CHPh}$ ), 8.02 (pseudo-t, $2 \mathrm{H}, J=1.9 \mathrm{~Hz}, \mathrm{NCHCH}$ ), 7.93 (pseudo$\mathrm{t}, 2 \mathrm{H}, J=1.9 \mathrm{~Hz}, \mathrm{NCHCH}), 7.44(\mathrm{~m}, 2 \mathrm{H}, \mathrm{Ph}), 7.59(\mathrm{~m}, 3 \mathrm{H}, \mathrm{Ph}), 3.90$ $\left(\mathrm{s}, 6 \mathrm{H}, \mathrm{CH}_{3}\right) .{ }^{13} \mathrm{C}\left\{{ }^{1} \mathrm{H}\right\} \quad \mathrm{NMR}\left(75 \mathrm{MHz}, \mathrm{DMSO}-d_{6}\right): \delta 137.9$ (NCHN), $131.1(\mathrm{Ph}), 131.0(\mathrm{Ph}), 129.6(\mathrm{Ph}), 127.6(\mathrm{Ph}), 125.1$ $(\mathrm{NCHCH}), 121.1(\mathrm{NCHCH}), 71.4(\mathrm{CHPh}), 36.4\left(\mathrm{CH}_{3}\right) . \mathrm{Mp}: 212{ }^{\circ} \mathrm{C}$ dec. MS $\left(\mathrm{ESI}^{+}, \mathrm{MeOH}\right): m / z 335[\mathrm{M}-\mathrm{Br}]^{+}, 253[\mathrm{M}-2 \mathrm{Br}]^{+}, 171$ $\left[\mathrm{M}-2 \mathrm{Br}-\mathrm{CH}_{3}-\mathrm{Im}\right]^{+}$.

Synthesis of 1,1-Bis(3-benzylimidazolium-1-yl)methane Dichloride (6b). A solution of 1-benzylimidazole $(3.00 \mathrm{~g}, 19.0 \mathrm{mmol})$ in dichloromethane $(50 \mathrm{~mL})$ was stirred in a $100 \mathrm{~mL}$ ACE glass autoclave at $110{ }^{\circ} \mathrm{C}$ for 3 days. The precipitate was filtered off and washed with DCM $(3 \times 5 \mathrm{~mL})$. Removal of the solvent under reduced pressure at $150{ }^{\circ} \mathrm{C}$ yielded the bis(imidazolium) salt $(2.26 \mathrm{~g}, 5.61$ $\mathrm{mmol}, 59 \%)$ as a hygroscopic white powder.

${ }^{1} \mathrm{H}$ NMR (300 MHz, DMSO- $d_{6}$ ): $\delta 9.97$ (s, 2H, NCHN), 8.25 (s, $2 \mathrm{H}, \mathrm{NCHCH}), 7.91$ (s, 2H, NCHCH), 7.41-7.45 (m, 10H, Ph), 6.82 $\left(\mathrm{s}, 2 \mathrm{H}, \mathrm{NCH}_{2} \mathrm{~N}\right), 5.50\left(\mathrm{~s}, 4 \mathrm{H}, \mathrm{CH}_{2}\right) \cdot{ }^{13} \mathrm{C}\left\{{ }^{1} \mathrm{H}\right\}$ NMR $(75 \mathrm{MHz}$, DMSO- $\left.d_{6}\right): \delta 138.8(\mathrm{NCHN}), 134.4\left(\mathrm{NCH}_{2} \mathrm{C}^{P h}\right), 130.7(\mathrm{Ph}), 130.5$ $(\mathrm{Ph}), 130.1(\mathrm{Ph}), 124.8(\mathrm{NCHCH}), 123.8(\mathrm{NCHCH}), 60.1$ $\left(\mathrm{NCH}_{2} \mathrm{~N}\right), 54.7\left(\mathrm{CH}_{2} \mathrm{Ph}\right) . \mathrm{MS}\left(\mathrm{ESI}^{+}, \mathrm{MeOH}\right): m / z 365[\mathrm{M}-\mathrm{Cl}]^{+}$, $329[\mathrm{M}-2 \mathrm{Cl}-\mathrm{H}]^{+}, 239[\mathrm{M}-2 \mathrm{Cl}-\mathrm{Bn}]^{+}$. Mp: $260{ }^{\circ} \mathrm{C}$ dec. Anal. Calcd for $\mathrm{C}_{21} \mathrm{H}_{22} \mathrm{Cl}_{2} \mathrm{~N}_{4}$ : C, 62.85; $\mathrm{H}, 5.53 ; \mathrm{N}, 13.96$. Found: $\mathrm{C}, 62.08$; $\mathrm{H}, 5.40$; N, 14.10.

Synthesis of 1,1-Bis(3-tert-butylimidazolium-1-yl)methane Dichloride (7b). A solution of tert-butylimidazole $(3.00 \mathrm{~g}, 24.2 \mathrm{mmol})$ in dichloromethane $(50 \mathrm{~mL})$ was stirred in a $100 \mathrm{~mL}$ ACE glass autoclave at $110{ }^{\circ} \mathrm{C}$ for 3 days. All volatiles were removed under reduced pressure, and the residue was dissolved in boiling $\mathrm{MeCN}$ (50 $\mathrm{mL}$ ). Into the warm $\mathrm{MeCN}$ solution was dropped $\mathrm{Et}_{2} \mathrm{O}$ until precepitation started. After $3 \mathrm{~h}$ at room temperature the mixture was filtered and the filtrate stored at $-20{ }^{\circ} \mathrm{C}$ overnight. The product precipitated as a white solid. After filtration, a second crop was obtained by addition of $\mathrm{Et}_{2} \mathrm{O}$ to the mother liquor and subsequent cooling. Filtration and removal of the solvents under reduced pressure at $120^{\circ} \mathrm{C}$ yielded the bis(imidazolium) salt ( $\left.1.41 \mathrm{~g}, 4.24 \mathrm{mmol}, 35 \%\right)$ as a hygroscopic white powder.

${ }^{1} \mathrm{H}$ NMR (300 MHz, DMSO- $d_{6}$ ): $\delta 10.45$ (pseudo-t, $2 \mathrm{H}, J=1.6 \mathrm{~Hz}$, $\mathrm{NCHN}$ ), 8.52 (pseudo-t, $2 \mathrm{H}, J=1.9 \mathrm{~Hz}, \mathrm{NCHCH}$ ), 8.17 (pseudo-t, $2 \mathrm{H}, J=1.9 \mathrm{~Hz}, \mathrm{NCHCH}), 6.83\left(\mathrm{~s}, 2 \mathrm{H}, \mathrm{NCH}_{2} \mathrm{~N}\right), 1.60\left(\mathrm{~s}, 18 \mathrm{H}, \mathrm{CH}_{3}\right)$. ${ }^{13} \mathrm{C}\left\{{ }^{1} \mathrm{H}\right\}$ NMR (75 MHz, DMSO- $\left.d_{6}\right): \delta 136.7$ (NCHN), 122.6 $(\mathrm{NCHCH}), 120.6(\mathrm{NCHCH}), 60.1\left(\mathrm{NCH}_{2} \mathrm{~N}\right), 57.2\left(\mathrm{C}_{\mathrm{q}}\right), 28.8\left(\mathrm{CH}_{3}\right)$. MS $\left(\mathrm{ESI}^{+}, \mathrm{MeOH}\right): m / z 297[\mathrm{M}-\mathrm{Cl}]^{+}, 261[\mathrm{M}-2 \mathrm{Cl}-\mathrm{H}]^{+}, 205$ $\left[\mathrm{M}-2 \mathrm{Cl}-{ }^{t} \mathrm{Bu}\right]^{+}, 149\left[\mathrm{M}-2 \mathrm{Cl}-2^{t} \mathrm{Bu}+\mathrm{H}\right]^{+}$. Mp: $\sim 140{ }^{\circ} \mathrm{C}$ dec. Anal. Calcd for $\mathrm{C}_{15} \mathrm{H}_{26} \mathrm{Cl}_{2} \mathrm{~N}_{4}$ : C, 54.05; H, 7.86; N, 16.81. Found C, 52.90; H, 7.90; N, 16.80 .

Synthesis of 1,1-Bis(3-adamantylimidazolium-1-yl)methane Dichloride (10b). Synthesis was performed according to the general procedure described above.

Yield: $3.61 \mathrm{~g}(7.38 \mathrm{mmol}, 59 \%) .{ }^{1} \mathrm{H}$ NMR $\left(300 \mathrm{MHz}\right.$, DMSO- $\left.d_{6}\right): \delta$ 10.34 (br s, $2 \mathrm{H}, \mathrm{NCHN}$ ), 8.41 (br s, $2 \mathrm{H}, \mathrm{NCHCH}$ ), 8.18 (br s, $2 \mathrm{H}$, $\mathrm{NCHCH}), 6.80\left(\right.$ br s, $\left.2 \mathrm{H}, \mathrm{NCH}_{2} \mathrm{~N}\right), 2.21\left(\mathrm{br} \mathrm{s}, 6 \mathrm{H}, \mathrm{CH}^{\mathrm{Ad}}\right), 2.06(\mathrm{br} \mathrm{s}$, $12 \mathrm{H}, \mathrm{CH}_{2}{ }^{\mathrm{Ad}}$ ), 1.71 (br s, $\left.12 \mathrm{H}, \mathrm{CH}_{2}{ }^{\mathrm{Ad}}\right) .{ }^{13} \mathrm{C}\left\{{ }^{1} \mathrm{H}\right\}$ NMR $(75 \mathrm{MHz}$, DMSO- $\left.d_{6}\right): \delta 136.1(\mathrm{NCHN}), 122.6(\mathrm{NCHCH}), 119.8(\mathrm{NCHCH})$, $59.8(\mathrm{NCH} 2 \mathrm{~N}), 57.5\left(\mathrm{NC}^{\mathrm{Ad}}\right), 41.3\left(\mathrm{NCCH}_{2}{ }^{\mathrm{Ad}}\right), 34.8\left(\mathrm{CH}_{2}{ }^{\mathrm{Ad}}\right), 28.8$ $\left(\mathrm{CH}^{\mathrm{Ad}}\right) . \mathrm{Mp}:>300{ }^{\circ} \mathrm{C}$. $\mathrm{MS}\left(\mathrm{ESI}^{+}, \mathrm{MeOH}\right): m / z 453[\mathrm{M}-\mathrm{Cl}]^{+}, 417$ $[\mathrm{M}-2 \mathrm{Cl}-\mathrm{H}]^{+}, 283[\mathrm{M}-2 \mathrm{Cl}-\mathrm{Ad}]^{+}, 135[\mathrm{Ad}]^{+}$.

General Procedure for the Synthesis of Dicarbene Iron(II) Dihalide Complexes. A suspension of the corresponding bis(imidazolium) salt $(1.00 \mathrm{mmol})$ in THF $(10 \mathrm{~mL})$ was treated with $\left[\mathrm{Fe}\left\{\mathrm{N}\left(\mathrm{SiMe}_{3}\right)_{2}\right\}_{2}\right]_{2} \quad(500 \mathrm{mg}, 0.67 \mathrm{mmol})$ and stirred at room temperature overnight. The precipitate was filtered off, washed with THF $(2 \times 3 \mathrm{~mL})$ and $\mathrm{Et}_{2} \mathrm{O}(2 \times 3 \mathrm{~mL})$, and then dried in vacuo. The desired complex was obtained as a white or brownish powder.

Complex 12. Yield: $340 \mathrm{mg}$ (0.84 mmol, 84\%). MS (EI): $\mathrm{m} / z 406$ $[\mathrm{M}]^{+}, 325[\mathrm{M}-\mathrm{Br}]^{+}$. $\mathrm{MB}\left(\mathrm{mm} \mathrm{s}^{-1}\right): \delta=0.73, \Delta E_{\mathrm{Q}}=3.94, \Gamma=0.28$ (contains some impurity according to Mössbauer data). Anal. Calcd for $\mathrm{C}_{10} \mathrm{H}_{14} \mathrm{Br}_{2} \mathrm{FeN}_{4}$ : C, 29.59; $\mathrm{H}, 3.48 ; \mathrm{N}, 13.80$. Found $\mathrm{C}, 29.92 ; \mathrm{H}$, $3.65 ; \mathrm{N}, 13.85$.

Complex 13. Yield: $336 \mathrm{mg}(0.80 \mathrm{mmol}, 80 \%) . \mathrm{MS}(\mathrm{EI}): \mathrm{m} / z 420$ $[\mathrm{M}]^{+}, 339[\mathrm{M}-\mathrm{Br}]^{+}, 257\left[\mathrm{M}-\mathrm{Br}-\mathrm{C}_{4} \mathrm{H}_{5} \mathrm{~N}_{2}\right]^{+}$. $\mathrm{MB}\left(\mathrm{mm} \mathrm{s}^{-1}\right): \delta=$ 0.74, $\Delta E_{\mathrm{Q}}=3.75, \Gamma=0.27$. Anal. Calcd for $\mathrm{C}_{11} \mathrm{H}_{16} \mathrm{Br}_{2} \mathrm{FeN}_{4}$ : C, 31.46; $\mathrm{H}, 3.84 ; \mathrm{N}, 13.34$. Found C, 32.57; H, 4.06; N, 12.68 .

Complex 15. Yield: $272 \mathrm{mg}(0.65 \mathrm{mmol}, 65 \%)$ as a brownish powder. Colorless single crystals suitable for X-ray diffraction were grown by slow evaporation of pentane into a $\mathrm{CH}_{2} \mathrm{Cl}_{2}$ solution at $8{ }^{\circ} \mathrm{C}$. 
MS (EI): $m / z 420[\mathrm{M}]^{+}, 339[\mathrm{M}-\mathrm{Br}]^{+}, 231[\mathrm{M}-2 \mathrm{Br}-\mathrm{Et}]^{+}, 175$ $\left[\mathrm{M}-\mathrm{FeBr}_{2}-\mathrm{Et}\right]^{+}$. MB $\left(\mathrm{mm} \mathrm{s}^{-1}\right): \delta=0.74, \Delta E_{\mathrm{Q}}=3.96, \Gamma=0.26$. Anal. Calcd for $\mathrm{C}_{11} \mathrm{H}_{16} \mathrm{Br}_{2} \mathrm{FeN}_{4}$ : C, 31.46; H, 3.84; N, 13.34. Found: C, 31.28; $\mathrm{H}, 3.71 ; \mathrm{N}, 13.43$.

Complex 16a. The reaction was carried out in $\mathrm{Et}_{2} \mathrm{O}$, and the precipitate was washed with $\mathrm{Et}_{2} \mathrm{O}(3 \times 5 \mathrm{~mL})$ only. Yield: $430 \mathrm{mg}$ $(0.79 \mathrm{mmol}, 79 \%)$ as a brownish powder. MS (EI): $\mathrm{m} / z 522[\mathrm{M}]^{+}$, $464[\mathrm{M}-\mathrm{Br}]^{+}, 237[\mathrm{M}-2 \mathrm{Br}-\mathrm{Bn}-\mathrm{Fe}]^{+}, 158\left[\mathrm{Bn}+\mathrm{C}_{3} \mathrm{H}_{3} \mathrm{~N}_{2}\right]^{+}, 91$ $[\mathrm{Bn}]^{+}$. MB $\left(\mathrm{mm} \mathrm{s}^{-1}\right): \delta=0.73, \Delta E_{\mathrm{Q}}=3.93, \Gamma=0.26$. Anal. Calcd for $\mathrm{C}_{21} \mathrm{H}_{20} \mathrm{Br}_{2} \mathrm{FeN}_{4}$ : C, 46.36; H, 3.71; N, 10.30. Found C, 45.64; H, 3.66; $\mathrm{N}, 10.39$.

Complex 16b. The reaction was carried out in $\mathrm{Et}_{2} \mathrm{O}$, and the precipitate was washed with $\mathrm{Et}_{2} \mathrm{O}(3 \times 5 \mathrm{~mL})$ only. Yield: $200 \mathrm{mg}$ (0.44 mmol, $44 \%)$ as a brownish powder. Colorless single crystals suitable for X-ray diffraction were grown by slow diffusion of pentane into a THF solution at $8{ }^{\circ} \mathrm{C}$. Mp: $98{ }^{\circ} \mathrm{C}$ dec. MS (EI): $m / z 455[\mathrm{M}]^{+}$, $420[\mathrm{M}-\mathrm{Cl}]^{+}, 275[\mathrm{M}-2 \mathrm{Bn}]^{+}, 158\left[\mathrm{Bn}+\mathrm{C}_{3} \mathrm{H}_{3} \mathrm{~N}_{2}\right]^{+}, 91[\mathrm{Bn}]^{+}$. MB $\left(\mathrm{mm} \mathrm{s}^{-1}\right): \delta=0.74, \Delta E_{\mathrm{Q}}=3.96, \Gamma=0.29$ (contains some impurity according to Mössbauer data). Anal. Calcd for $\mathrm{C}_{21} \mathrm{H}_{20} \mathrm{Cl}_{2} \mathrm{FeN}_{4}$ : C, 55.41; H, 4.43; N, 12.31. Found: C, 55.17; H, 4.37; N, 12.26.

Complex 17a. Yield: $353 \mathrm{mg}$ (0.83 mmol, 83\%). Tiny colorless single crystals suitable for X-ray diffraction were obtained by crystallization from hot acetonitrile, although most of the complex decomposes by this method. ${ }^{1} \mathrm{H}$ NMR (300 MHz, DMSO- $\left.d_{6}\right): \delta 55.73$ (br), 34.87 (br), 27.75 (br), 23.65 (br), 17.86 (br), 9.02 (br), 6.17 (br), 0.90 (br). MS (EI): $m / z 476[\mathrm{M}]^{+}, 395[\mathrm{M}-\mathrm{Br}]^{+}, 339[\mathrm{M}-$ $\left.{ }^{t} \mathrm{Bu}-\mathrm{Br}\right]^{+}, 283\left[\mathrm{M}-2^{t} \mathrm{Bu}-\mathrm{Br}+\mathrm{H}\right]^{+} . \mathrm{MB}\left(\mathrm{mm} \mathrm{s}^{-1}\right): \delta=0.79$, $\Delta E_{\mathrm{Q}}=3.78, \Gamma=0.31$. UV-vis (DCM solution): $\lambda_{\max }(\mathrm{nm})\left(\varepsilon\left(\mathrm{M}^{-1} \mathrm{~cm}^{-1}\right)\right)$ : 333 ( 1600). Anal. Calcd for $\mathrm{C}_{15} \mathrm{H}_{24} \mathrm{Br}_{2} \mathrm{FeN}_{4}$ : C, 37.85; H, 5.08; N, 11.77. Found: C, 37.69; H, 5.26; N, 11.65 .

Complex 17b. The reaction was carried out in $\mathrm{Et}_{2} \mathrm{O}$, and the precipitate was washed with $\mathrm{Et}_{2} \mathrm{O}(3 \times 5 \mathrm{~mL})$ only. Yield: $213 \mathrm{mg}$ (0.55 mmol, 55\%). MS (EI): $m / z 386[\mathrm{M}]^{+}, 351[\mathrm{M}-\mathrm{Cl}]^{+}, 330[\mathrm{M}-$ $\left.{ }^{t} \mathrm{Bu}\right]^{+}, 295\left[\mathrm{M}-\mathrm{Cl}-{ }^{t} \mathrm{Bu}\right]^{+}, 148\left[\left(\mathrm{C}_{3} \mathrm{H}_{3} \mathrm{~N}_{2}\right)_{2} \mathrm{CH}_{2}\right]^{+} . \mathrm{MB}\left(\mathrm{mm} \mathrm{s}^{-1}\right): \delta=$ 0.80, $\Delta E_{\mathrm{O}}=3.87, \Gamma=0.29$. Anal. Calcd for $\mathrm{C}_{15} \mathrm{H}_{24} \mathrm{Cl}_{2} \mathrm{FeN}_{4}$ : C, 46.54; H, 6.25; N, 14.47. Found C, 45.15; H, 6.04; N, 13.85 .

Complex 18a. Colorless single crystals suitable for X-ray diffraction were obtained from a reaction mixture containing $8 \mathrm{a}$ and $\left[\mathrm{Fe}\left\{\mathrm{N}\left(\mathrm{SiMe}_{3}\right)_{2}\right\}_{3}\right]$ in THF at $-30{ }^{\circ} \mathrm{C}$. Yield: $490 \mathrm{mg}(0.82 \mathrm{mmol}$, $82 \%) .{ }^{1} \mathrm{H}$ NMR (300 MHz, DMSO- $d_{6}$ ): $\delta 59.02(\mathrm{br}, 2 \mathrm{H}), 21.93(\mathrm{br}$, $2 \mathrm{H}), 9.02(2 \mathrm{H}), 5.65$ (br, 4H) $3.03(\mathrm{br}, 6 \mathrm{H}),-4.82$ (br, 12H). MS (EI): $m / z 600[\mathrm{M}]^{+}, 519[\mathrm{M}-\mathrm{Br}]^{+}$. Mp: $155^{\circ} \mathrm{C} \mathrm{dec.} \mathrm{MB}\left(\mathrm{mm} \mathrm{s}^{-1}\right)$ : $\delta=0.74, \Delta E_{\mathrm{Q}}=4.03, \Gamma=0.26$. UV-vis (DCM solution): $\lambda_{\max }(\mathrm{nm})$ $\left(\varepsilon\left(\mathrm{M}^{-1} \mathrm{~cm}^{-1}\right)\right): 347(\sim 1600)$. Anal. Calcd for $\mathrm{C}_{25} \mathrm{H}_{28} \mathrm{Br}_{2} \mathrm{FeN}_{4}: \mathrm{C}$, 50.03; H, 4.70; N, 9.34. Found: C, 50.10; H, 4.70; N, 9.26.

Complex 18b. Yield: $439 \mathrm{mg}(0.86 \mathrm{mmol}, 86 \%)$. ${ }^{1} \mathrm{H}$ NMR (500 $\mathrm{MHz}, \mathrm{CD}_{2} \mathrm{Cl}_{2}$ ): $\delta 57.78$ (br), 20.49 (br), 5.16 (br), 2.50 (br), -4.08 (br). MS (EI): $m / z 510[\mathrm{M}]^{+}, 475[\mathrm{M}-\mathrm{Cl}]^{+}$. MB $\left(\mathrm{mm} \mathrm{s}^{-1}\right): \delta=$ $0.77, \Delta E_{\mathrm{O}}=3.88, \Gamma=0.27$. UV-vis (DCM solution): $\lambda_{\max }(\mathrm{nm})(\varepsilon$ $\left.\left(\mathrm{M}^{-1} \mathrm{~cm}^{-1}\right)\right): 345(\sim 1500)$. Anal. Calcd for $\mathrm{C}_{25} \mathrm{H}_{28} \mathrm{Cl}_{2} \mathrm{FeN}_{4}$ : C, 58.73; H, 5.52; N, 10.96. Found: C, 58.64; H, 5.65; N, 10.90 .

Complex 19. A suspension of bis(imidazolium) salt 9 ( $1.00 \mathrm{~g}, 1.78$ $\mathrm{mmol})$ in $\mathrm{Et}_{2} \mathrm{O}(20 \mathrm{~mL})$ was treated with $\left[\mathrm{Fe}\left\{\mathrm{N}\left(\mathrm{SiMe}_{3}\right)_{2}\right\}_{2}\right]_{2}(880$ $\mathrm{mg}, 1.17 \mathrm{mmol}$ ) and stirred overnight at room temperature. The precipitate was filtered off and washed with $\mathrm{Et}_{2} \mathrm{O}(3 \times 3 \mathrm{~mL})$; afterward the solid was stirred in $\mathrm{CH}_{2} \mathrm{Cl}_{2}$ for $10 \mathrm{~min}$, filtered, and washed with $\mathrm{Et}_{2} \mathrm{O}(2 \times 3 \mathrm{~mL})$. Complex 19 was obtained as a white powder (742 mg, $1.21 \mathrm{mmol}, 68 \%$ ) upon removal of the solvents in vacuo. Colorless single crystals suitable for X-ray diffraction were grown by slow evaporation of pentane into a THF solution at $8{ }^{\circ} \mathrm{C} .{ }^{1} \mathrm{H}$ NMR (300 MHz, $\mathrm{CD}_{2} \mathrm{Cl}_{2}$ ): $\delta 42.72$ (br), 34.73 (br), 23.71 (br), 8.40 (br), 4.76 (br), 0.08 (br). MS (EI): $m / z 614[\mathrm{M}]^{+}, 533[\mathrm{M}-\mathrm{Br}]^{+}$. Mp: $160{ }^{\circ} \mathrm{C}$ dec. UV-vis (DCM solution): $\lambda_{\max }(\mathrm{nm})\left(\varepsilon\left(\mathrm{M}^{-1}\right.\right.$ $\left.\left.\mathrm{cm}^{-1}\right)\right): 335(\sim 1800) . \mathrm{MB}\left(\mathrm{mm} \mathrm{s}^{-1}\right): \delta=0.77, \Delta E_{\mathrm{O}}=3.91, \Gamma=0.26$. Anal. Calcd for $\mathrm{C}_{26} \mathrm{H}_{30} \mathrm{Br}_{2} \mathrm{FeN}_{4}$ : C, 50.84; H, 4.92; N, 9.12. Found: C, 50.42; H, 4.96; N, 9.00 .

Complex 20a. The reaction was carried out in $40 \mathrm{~mL}$ of THF per $1.0 \mathrm{mmol}$ of bis(imidazolium) salt, and the precipitate was washed with THF $(3 \times 5 \mathrm{~mL})$ and $\mathrm{Et}_{2} \mathrm{O}(3 \times 5 \mathrm{~mL})$. Yield: $537 \mathrm{mg}(0.85$ mmol, 85\%). MS (EI): $m / z 632[\mathrm{M}]^{+}, 551[\mathrm{M}-\mathrm{Br}]^{+}, 202[\mathrm{Ad}+$
$\left.\mathrm{C}_{3} \mathrm{H}_{3} \mathrm{~N}_{2}\right]^{+}, 135[\mathrm{Ad}]^{+} . \mathrm{MB}\left(\mathrm{mm} \mathrm{s}^{-1}\right): \delta=0.78, \Delta E_{\mathrm{Q}}=3.79, \Gamma=0.28$. Anal. Calcd for $\mathrm{C}_{27} \mathrm{H}_{36} \mathrm{Br}_{2} \mathrm{FeN}_{4}$ : C, 51.29; H, 5.74; N, 8.86. Found: C, 51.17; H, 5.94; N, 8.55.

Complex 20b. The reaction was carried out in $40 \mathrm{~mL}$ of THF per $1.0 \mathrm{mmol}$ of bis(imidazolium) salt, and the precipitate was washed with THF $(3 \times 5 \mathrm{~mL})$ and $\mathrm{Et}_{2} \mathrm{O}(3 \times 5 \mathrm{~mL})$. Yield: $542 \mathrm{mg}(0.63$ mmol, 63\%). MS (EI): $m / z 542[\mathrm{M}]^{+}, 507[\mathrm{M}-\mathrm{Cl}]^{+}, 202[\mathrm{Ad}+$ $\left.\mathrm{C}_{3} \mathrm{H}_{3} \mathrm{~N}_{2}\right]^{+}, 135[\mathrm{Ad}]^{+} . \mathrm{MB}\left(\mathrm{mm} \mathrm{s}^{-1}\right): \delta=0.81, \Delta E_{\mathrm{Q}}=3.67, \Gamma=0.26$. Anal. Calcd for $\mathrm{C}_{27} \mathrm{H}_{36} \mathrm{Cl}_{2} \mathrm{FeN}_{4}$ : C, 59.68; H, 6.68; N, 10.31. Found: C, 59.40; H, 6.96; N, 10.04 .

Complex 24. A suspension of the bis(imidazolium) salt 1 (676 mg, $2.00 \mathrm{mmol})$ in $\mathrm{MeCN}(15 \mathrm{~mL})$ was treated with $\left[\mathrm{Fe}\left\{\mathrm{N}\left(\mathrm{SiMe}_{3}\right)_{2}\right\}_{2}\right]_{2}$ (942 mg, $1.25 \mathrm{mmol}$ ) and stirred overnight at room temperature. The precipitate was filtered off and washed with THF $(5 \mathrm{~mL})$ and $\mathrm{Et}_{2} \mathrm{O}$ $(5 \mathrm{~mL})$. The desired complex was obtained as a yellow powder $(745$ $\mathrm{mg}, 0.86 \mathrm{mmol}, 86 \%)$ upon drying under vacuum. Yellow single crystals suitable for $\mathrm{X}$-ray diffraction were grown by slow diffusion of $\mathrm{Et}_{2} \mathrm{O}$ into a solution of the product in $\mathrm{MeCN}$. MS $\left(\mathrm{ESI}^{+}, \mathrm{MeCN}\right)$ : $m / z 702.8[\mathrm{M}-\mathrm{FeBr}-\mathrm{MeCN}-\mathrm{H}]^{+}, 487.1\left[\mathrm{M}-\mathrm{FeBr}_{3}-\right.$ $2 \mathrm{MeCN}^{+}, 204\left[\mathrm{~L}_{2} \mathrm{Fe}\right]^{2+} . \mathrm{MB}\left(\mathrm{mm} \mathrm{s}^{-1}\right):\left[\mathrm{L}_{2} \mathrm{Fe}(\mathrm{MeCN})_{2}\right]^{2+} \delta=0.15$, $\Delta E_{\mathrm{Q}}=1.36, \Gamma=0.38 ;\left[\mathrm{FeBr}_{4}\right]^{2-} \delta=1.05, \Delta E_{\mathrm{Q}}=2.88, \Gamma=0.51$. Anal. Calcd for $\mathrm{C}_{22} \mathrm{H}_{30} \mathrm{Br}_{4} \mathrm{Fe}_{2} \mathrm{~N}_{10}$ : C, 30.52; H, 3.49; N, 16.18. Found: C, $29.61 ; \mathrm{H}, 3.43 ; \mathrm{N}, 15.78$.

Complexes 14 and 22. A suspension of the bis(imidazolium) salt $4(1.00 \mathrm{~g}, 2.41 \mathrm{mmol})$ in THF $(15 \mathrm{~mL})$ was treated with $[\mathrm{Fe}\{\mathrm{N}$ $\left.\left.\left(\mathrm{SiMe}_{3}\right)_{2}\right\}_{2}\right]_{2}(1.00 \mathrm{~g}, 1.33 \mathrm{mmol})$ and stirred at room temperature overnight. The precipitate was filtered off and washed with THF $(2 \times$ $10 \mathrm{~mL}$ ). The green tetracarbene complex was separated from the colorless dicarbene complex by rinsing with DCM $(3 \times 20 \mathrm{~mL})$. The filtrate was concentrated to $3 \mathrm{~mL}$ and filtered again. Evaporation of the solvent from the filtrate afforded 22 as a green solid $(305 \mathrm{mg}, 0.42$ $\mathrm{mmol}, 35 \%)$. Yellow single crystals of $\mathbf{2 5}$ suitable for X-ray diffraction were obtained by slow diffusion of $\mathrm{Et}_{2} \mathrm{O}$ into a $\mathrm{MeCN}$ solution of 22 . The residue from the second filtration was washed with $\mathrm{Et}_{2} \mathrm{O}$ and dried in vacuo, affording 14 as a greenish powder $(260 \mathrm{mg}, 0.43 \mathrm{mmol}$, $18 \%)$. Colorless single crystals suitable for $\mathrm{X}$-ray diffraction were grown from $\mathrm{CH}_{2} \mathrm{Cl}_{2}$ solution by cooling to $-30{ }^{\circ} \mathrm{C}$ for 1 week. Analytical data for crystalline material of $\mathbf{1 4}$ are as follows. MS (EI): $m / z 468[\mathrm{M}]^{+}, 387[\mathrm{M}-\mathrm{Br}]^{+}, 307[\mathrm{M}-2 \mathrm{Br}]^{+}, 252[\mathrm{M}-2 \mathrm{Br}-$ $\mathrm{Fe}]^{+}$. UV-vis (DCM solution): $\lambda_{\text {max }}(\mathrm{nm})\left(\varepsilon\left(\mathrm{M}^{-1} \mathrm{~cm}^{-1}\right)\right): 712$ ( 500), 360 ( 2000). Anal. Calcd for $\mathrm{C}_{15} \mathrm{H}_{16} \mathrm{Br}_{2} \mathrm{FeN}_{4}: \mathrm{C}, 38.50 ; \mathrm{H}$, 3.45; N, 11.97. Found: C, 39.00; H, 3.90; N, 11.44.

General Procedure for Cross-Coupling Reactions. A dried Schlenk tube was charged with catalyst, bromo- or chlorocyclohexane $(1.00 \mathrm{mmol})$, and $\mathrm{Et}_{2} \mathrm{O}(3 \mathrm{~mL})$ in a glovebox. Under argon $p$ tolylmagnesium bromide solution $(3.00 \mathrm{~mL}, 1.50 \mathrm{mmol}, 0.5 \mathrm{M}$ in $\mathrm{Et}_{2} \mathrm{O}$ ) was added at room temperature. The reaction mixture was stirred at $45{ }^{\circ} \mathrm{C}$ oil bath temperature for $30 \mathrm{~min}$. The reaction mixture was quenched with $\mathrm{H}_{2} \mathrm{O}(5 \mathrm{~mL})$ and extracted with $\mathrm{CH}_{2} \mathrm{Cl}_{2}(3 \times 10$ $\mathrm{mL})$. The organic phase was dried with $\mathrm{MgSO}_{4}$. All volatiles were removed in vacuo, and 1,3,5-trimethoxybenzene $(0.25 \mathrm{mmol})$ was added to the remaining oil/solid as an internal standard for ${ }^{1} \mathrm{H}$ NMR conversion determination. Identification of the products and side products was performed by GC/MS of the organic phase after workup.

\section{ASSOCIATED CONTENT}

\section{S Supporting Information}

Figures giving the Mössbauer spectrum of $19, \mathrm{CV}$ spectrum of 17a, and X-ray structures of 18a, 25, and 26 and CIF files giving crystallographic data for $4,14,15,16 b, 17 a, 18 a, 19$, and 24-26. This material is available free of charge via the Internet at http://pubs.acs.org.

\section{AUTHOR INFORMATION}

\section{Corresponding Author}

*Tel: +49 551 393012. Fax: +49 551 393063. E-mail: franc. meyer@chemie.uni-goettingen.de. 


\section{ACKNOWLEDGMENTS}

Financial support by the DFG (International Research Training Group IGRK 1422 "Metal Sites in Biomolecules: Structures, Regulation and Mechanisms"; see www.biometals.eu) is gratefully acknowledged.

\section{REFERENCES}

(1) (a) Bourissou, D.; Guerret, O.; Gabbaï, F. P.; Bertrand, G. Chem. Rev. 2000, 100, 39. (b) Weskamp, T.; Böhm, V. P. W.; Herrmann, W. A. J. Organomet. Chem. 2000, 600, 12. (c) Herrmann, W. A. Angew. Chem., Int. Ed. 2002, 41, 1290. (d) Hahn, F. E. Angew. Chem., Int. Ed. 2006, 45, 1348. (e) Díez-González, S.; Marion, N.; Nolan, S. P. Chem. Rev. 2009, 109, 3612. (f) Jahnke, M. C.; Hahn, F. E. Top. Organomet. Chem. 2010, 30, 95. (g) Fortman, G. C.; Nolan, S. P. Chem. Soc. Rev. 2011, 40, 5151.

(2) N-Heterocyclic Carbenes in Transition Metal Catalysis and Organocatalysis; Cazin, C. S. J., Ed.; Springer: Amsterdam, 2010.

(3) (a) Hitchcock, P. B.; Lappert, M. F.; Thomas, S. A.; Thorne, A. J. J. Organomet. Chem. 1986, 315, 27. (b) Louie, J; Grubbs, R. H. Chem. Commun. 2000, 1479. (c) Buchgraber, P.; Toupet, L.; Guerchais, V. Organometallics 2003, 22, 5144. (d) Mercs, L.; Labat, G.; Neels, A.; Ehlers, A.; Albrecht, M. Organometallics 2006, 25, 5648. (e) Chen, M.-Z.; Sun, H.-M.; Li, W.-F.; Wang, Z.-G.; Shen, Q.; Zhang, Y. J. Organomet. Chem. 2006, 691, 2489. (f) Llewellyn, S. A.; Green, M. L. H.; Green, J. C.; Cowley, A. R. Dalton Trans. 2006, 2535. (g) Ohki, Y.; Hatanaka, T.; Tatsumi, K. J. Am. Chem. Soc. 2008, 130, 17174. (h) Mercs, L.; Neels, A.; Albrecht, M. Dalton Trans. 2008, 5570. (i) Kaufhold, O.; Hahn, F. E.; Pape, T.; Hepp, A. J. Organomet. Chem. 2008, 693, 3435. (j) Li, B.; Liu, T.; Popescu, C. V.; Bilko, A.; Darensbourg, M. Y. Inorg. Chem. 2009, 48, 11283. (k) Kandepi, V. V. K. M.; Cardoso, J. M. S.; Peris, E.; Royo, B. Organometallics 2010, 29, 2777. (1) Flores-Figueroa, A; Pape, T.; Weigand, J. J.; Hahn, F. E. Eur. J. Inorg. Chem. 2010, 19, 2907. (m) Hatanaka, T.; Ohki, Y.; Tatsumi, K. Chem. Asian J. 2010, 5, 1657. (n) Xiang, L.; Xiao, J.; Deng, L. Organometallics 2011, 30, 2018.

(4) Gao, H.; Yan, C.; Tao, X.-P.; Xia, Y.; Sun, H.-M.; Shen, Q.; Zhang, Y. Organometallics 2010, 29, 4189.

(5) Wang, Y.-S.; Sun, H.-M.; Tao, X.-P.; Shen, Q.; Zhang, Y. Chin. Sci. Bull. 2007, 52, 3193.

(6) For example, see: (a) Nehete, U. N.; Anantharaman, G.; Chandrasekhar, V.; Murugavel, R.; Walawalkar, M. G.; Roesky, H. W.; Vidovic, D.; Magull, J.; Samwer, K.; Sass, B. Angew. Chem., Int. Ed. 2004, 43, 3832. (b) Liu, T.; Darensbourg, M. Y. J. Am. Chem. Soc. 2007, 129, 7008. (c) Deng, L.; Holm, R. H. J. Am. Chem. Soc. 2008, 130, 9878. (d) Lavallo, V.; Grubbs, R. H. Science 2009, 326, 559.

(7) For examples of polymerization reactions, see: (a) Hatakeyama, T.; Hashimoto, S.; Ishizuka, K.; Nakamura, M. J. Am. Chem. Soc. 2009, 131, 11949. (b) Rosa, J. N.; Reddy, R. S.; Candeias, N. R.; Cal, P. M. S. D.; Gois, P. M. P. Org. Lett. 2010, 12, 2686.

(8) For examples of $\mathrm{C}-\mathrm{C}$ cross-coupling reactions, see: (a) Martin, R.; Fürstner, A. Angew. Chem., Int. Ed. 2004, 43, 3955. (b) Nakamura, M.; Matsuo, K.; Ito, S.; Nakamura, E. J. Am. Chem. Soc. 2004, 126, 3686. (c) Nagano, T.; Hayashi, T. Org. Lett. 2004, 6, 1297. (d) Bedford, R. B.; Bruce, D. W.; Frost, R. M.; Goodby, J. W.; Hird, M. Chem. Commun. 2004, 2822. (e) Bedford, R. B.; Bruce, D. W.; Frost, R. M.; Hird, M. Chem. Commun. 2005, 4161. (f) Bedford, R. B.; Betham, M.; Bruce, D. W.; Davis, S. A.; Frost, R. M.; Hird, M. Chem. Commun. 2006, 1398. (g) Bedford, R. B.; Betham, M.; Bruce, D. W.; Danopoulos, A. A.; Frost, R. M.; Hird, M. J. Org. Chem. 2006, 71, 1104. (h) Bica, K.; Gaertner, P. Org. Lett. 2006, 8, 733. (i) Hatakeyama, T.; Nakamura, M. J. Am. Chem. Soc. 2007, 129, 9844. (j) Fürstner, A.; Martin, R.; Krause, H.; Seidel, G.; Goddard, R.; Lehmann, C. W. J. Am. Chem. Soc. 2008, 130, 8773. (k) Chowdhury, R. R.; Crane, A. K.; Fowler, C.; Kwong, P.; Kozak, C. M. Chem. Commun. 2008, 94. (1) Qian, X.; Dawe, L. N.; Kozak, C. M. Dalton Trans. 2011, 40, 933.

(9) (a) McGuinness, D. S.; Gibson, V. C.; Steed, J. W. Organometallics 2004, 23, 6288. (b) Danopoulos, A. A.; Tsoureas, N.; Wright, J. A.; Light, M. E. Organometallics 2004, 23, 166. (c) Danopoulos, A. A.; Wright, J. A.; Motherwell, W. B. Chem. Commun. 2005, 784. (d) Pugh, D.; Wells, N. J.; Evans, D. J.; Danopoulos, A. A. Dalton Trans. 2009, 7189. (e) Danopoulos, A. A.; Pugh, D.; Smith, H.; Saßmannshausen, J. Chem. Eur. J. 2009, 15, 5491.

(10) (a) Kernbach, U.; Ramm, M.; Luger, P.; Fehlhammer, W. P. Angew. Chem., Int. Ed. 1996, 35, 310. (b) Fränkel, R; Kernbach, U.; Bakola-Christianopoulou, M.; Plaia, U.; Suter, M.; Ponikwar, W.; Nöth, H.; Moinet, C.; Fehlhammer, W. P. J. Organomet. Chem. 2001, 617618, 530. (c) Nieto, I.; Cervantes-Lee, F.; Smith, J. M. Chem. Commun. 2005, 3811. (d) Scepaniak, J. J.; Fulton, M. D.; Bontchev, R. P.; Duesler, E. N.; Kirk, M. L.; Smith, J. M. J. Am. Chem. Soc. 2008, 130, 10515. (e) Nieto, I.; Ding, F.; Bontchev, R. P.; Wang, H.; Smith, J. M. J. Am. Chem. Soc. 2008, 130, 2716. (f) Scepaniak, J. J.; Young, J. A.; Bontchev, R. P.; Smith, J. M. Angew. Chem., Int. Ed. 2009, 48, 3158. (g) Scepaniak, J. J.; Harris, T. D.; Vogel, C. S.; Sutter, J.; Meyer, K.; Smith, J. M. J. Am. Chem. Soc. 2011, 133, 3824.

(11) Vogel, C. S.; Heinemann, F. W.; Sutter, J.; Anthon, C.; Meyer, K. Angew. Chem., Int. Ed. 2008, 47, 2681.

(12) Liu, B.; Xia, Q.; Chen, W. Angew. Chem., Int. Ed. 2009, 48, 5513.

(13) Morvan, D.; Capon., J.-F.; Gloaguen, F.; Le Goff, A.; Marchivie, M.; Michaud, F.; Schollhammer, P.; Talarmin, J.; Yaouanc, J.-J. Organometallics 2007, 26, 2042.

(14) For examples, see: (a) Herrmann, W. A.; Reisinger, C.-P.; Spiegler, M. J. Organomet. Chem. 1998, 557, 93. (b) Hahn, F. E.; Foth, M. J. Organomet. Chem. 1999, 585, 241. (c) Taige, M. A.; Zeller, A.; Ahrens, S.; Goutal, S.; Herdtweck, E.; Strassner, T. J. Organomet. Chem. 2007, 692, 1519.

(15) (a) Hahn, F. E.; Tamm, M. J. Chem. Soc., Chem. Commun. 1993, 842. (b) Hahn, F. E.; Tamm, M. J. Chem. Soc., Chem. Commun. 1995, 596. (c) Hahn, F. E.; Tamm, M. Organometallics 1995, 14, 2597.

(16) Kantchev, E. A. B.; O’Brien, C. J.; Organ, M. G. Angew. Chem., Int. Ed. 2007, 46, 2768.

(17) Andersen, R. A.; Faegri, K.; Green, J. C.; Haaland, A.; Lappert, M. F.; Leung, W.-P.; Rypdal, K. Inorg. Chem. 1988, 27, 1782.

(18) Zlatogorsky, S.; Muryn, C. A.; Tuna, F.; Evans, D. J.; Ingleson, M. J. Organometallics 2011, 30, 4974.

(19) Scherg, T; Schneider, S. K.; Frey, G. D.; Schwarz, J.; Herdtweck, E.; Herrmann, W. A. Synlett 2006, 18, 2894.

(20) Nachtigall, F. M.; Corilo, Y. E.; Cassol, C. C.; Ebeling, G.; Morgon, N. H.; Dupont, J.; Eberlin, M. N. Angew. Chem. 2008, 120, 157.

(21) Okuyama, K.; Sugiyama, J.; Nagahata, R.; Asai, M.; Ueda, M.; Takeuchi, K. J. Mol. Catal. A: Chem. 2003, 203, 21.

(22) Noujeim, N.; Leclercq, L.; Schmitzer, A. R. J. Org. Chem. 2008, 73, 3784.

(23) Ahrens, S.; Strassner, T. Inorg. Chim. Acta 2006, 359, 4789.

(24) Lee, H. M.; Lu, C. Y.; Chen, C. Y.; Chen, W. L.; Lin, H. C.; Chiu, P. L.; Cheng, P. Y. Tetrahedron 2004, 60, 5807.

(25) Steiner, T. Acta Crystallogr. 1998, B54, 456.

(26) (a) Kreisel, K. A.; Yap, G. P. A.; Theopold, K. H. Organometallics 2006, 25, 4670. (b) Meyer, S.; Demeshko, S.; Dechert, S.; Meyer, F. Inorg. Chim. Acta 2010, 363, 3088.

(27) (a) Fackler, J. P.; Moyer, T.; Costamagna, J. A.; Latorre, R.; Granifo, J. Inorg. Chem. 1987, 26, 836. (b) Sproules, S.; Wieghardt, K. Coord. Chem. Rev. 2010, 254, 1358.

(28) Edwards, P. R.; Johnson, C. E.; Williams, R. J. P. J. Chem. Phys. 1967, 47, 2074.

(29) Low signal-to-noise ratio is due to $\gamma$ absorption by bromide. The area ratio of 55:45, which deviates from the theoretically expected ratio of 50:50, can probably be explained by higher Lamb-Mössbauer factors for ls than for hs iron(II) ions and deviation of the absorption peaks from ideal Lorentz function. Also, some small amount of the tetracarbene dication with one or two nonferrous anions cannot be fully excluded.

(30) Metal-Catalyzed Cross-Coupling Reactions; de Meijere, A., Diederich, F., Eds.; Wiley-VCH: Weinheim, Germany, 2004.

(31) Jana, R.; Pathak, T. P.; Sigman, M. S. Chem. Rev. 2011, 111, 1417.

(32) Frisch, A. C.; Beller, M. Angew. Chem., Int. Ed. 2005, 44, 674. 
(33) Netherton, M. R; Fu, G. C. Adv. Synth. Catal. 2004, 346, 1525.

(34) (a) Tamura, M.; Kochi, J. K. J. Am. Chem. Soc. 1971, 93, 1487.

(b) Tamura, M.; Kochi, J. K. Synthesis 1971, 6, 303. (c) Kochi, J. K. Acc. Chem. Res. 1974, 7, 351. (d) Neumann, S. M.; Kochi, J. K. J. Org. Chem. 1975, 40, 599. (e) Smith, R. S.; Kochi, J. K. J. Org. Chem. 1976, 41, 502. (f) Kochi, J. K. J. Organomet. Chem. 2002, 653, 11.

(35) (a) Fürstner, A.; Leitner, A.; Méndez, M.; Krause, H. J. Am. Chem. Soc. 2002, 124, 13856. (b) Bogdanović, B.; Schwickardi, M. Angew. Chem., Int. Ed. 2000, 39, 4610.

(36) Raynal, M.; Cazin, C. S. J.; Vallée, C.; Olivier-Bourbigou, H.; Braunstein, P. Dalton Trans. 2009, 3824.

(37) Scheele, U. J. Entwicklung von Übergangsmetallkomplexen mit neuartigen Pyrazol-NHC und Pyridazin-NHC-Hybridliganden; Dissertation, Cuvillier Verlag: Göttingen, Germany, 2008.

(38) Hayat, S.; Rahman, A.; Choudhary, M. I.; Khan, K. M.; Schuhmann, W.; Bayer, E. Tetrahedron 2001, 57, 9951.

(39) Bill, E. Mfit; Max-Planck Institute for Bioinorganic Chemistry, Mülheim/Ruhr, Germany.

(40) Bill, E. julX; Max-Planck Institute for Bioinorganic Chemistry, Mülheim/Ruhr, Germany.

(41) Sheldrick, G. M. Acta Crystallogr. 2008, A64, 112.

(42) Flack, H. D. Acta Crystallogr. 1983, A39, 876.

(43) X-RED; STOE \& CIE GmbH, Darmstadt, Germany, 2002. 